\title{
Galen
}

on the passions and errors of the soul

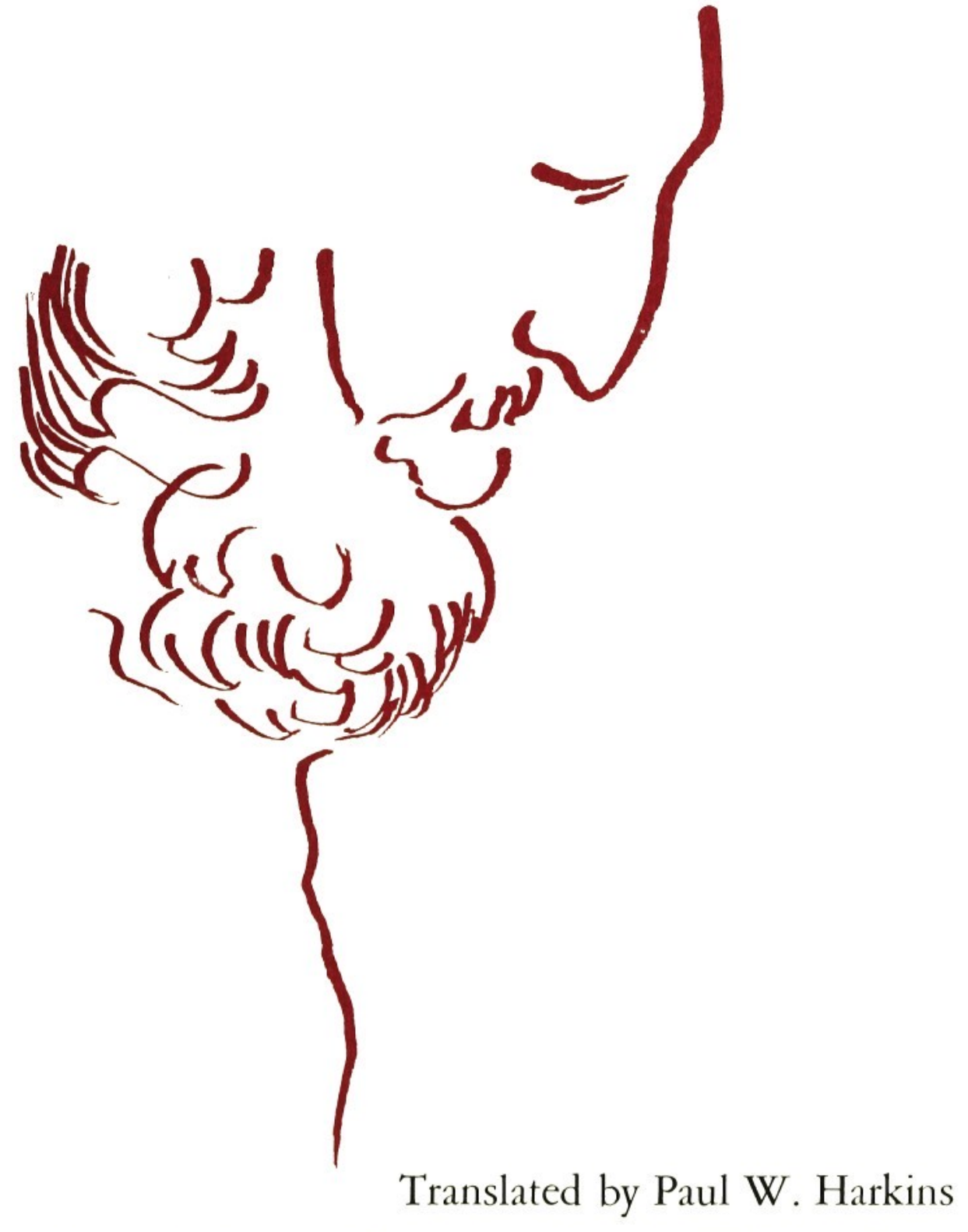

With an Introduction and Interpretation by Walther Riese 
For almost fifteen bundred years, Galen of Pergamum (130-ca. 200 A.D.) was the virtually undisputed authority in medical matters. He composed, it is said, nearly five bundred treatises in anatomy, pbysiology, and patbology, and such varied fields as logic, ethics, and grammar, as well as therapeutic and clinical works. His scientific approach to anatomy and bis use of inductive reasoning in the diagnosis of disease made bim the unquestioned "Prince of Pbysicians" until the early sixteenth century.

The present volume offers for the first time in English translation bis two works in the field of "moral philosophy," an area that, in the manner in which be approaches them, makes them contributions to that part of medicine known today as psychotherapy.

It was Galen's thesis that passion and moral error were diseases, but diseases of the soul and not the body, and that the physician treating a patient suffering from a "diseased soul" must attack the passion or error directly and immediately an approach that bas bad a profound infuence on the subsequent treatment of mental disorder.

Paul W. Harkins, professor of classical languages at Xavier University, Cincinnati, Obio, is the author of "St. Jobn Chrysostom: Baptismal Instructions" and is a frequent contributor to scholarly journals.

Walther Riese is emeritus associate professor of the history of medicine and neurology and psychiatry at the Medical College of Virginia. He is the autbor of "Principles of Neurology in the Light of History and Their Present Use"; "The Conception of Disease, Its History, Its Versions, and Its Nature"; "A History of Neurology"; and other books, and bas written numerous aricles for scientific periodicals in bolb Europe and the United States. 




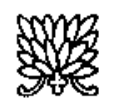

\section{GALEN on the passions and errors of the soul}

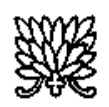




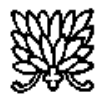

The publication of this volume was made possible, in part, by a contribution from the Committee for Research and Advanced Study of Xavier University

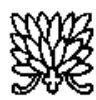




\section{GALEN}

on the passions and errors of the soul

$$
\text { s }
$$

Translated by

\section{PAUL W. HARKINS}

With an Introduction and Interpretation by

WALTHER RIESE

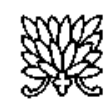

Ohio State University Press 


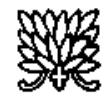

Copyright (C) 1963 by the Ohio State University Press All Rights Reserved

Library of Congress Catalogue Card Number: 63-18104

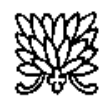




\title{
CONTENTS
}

\author{
Introduction / 1
}

Translator's Preface / 23

The Diagnosis and Cure of the Soul's Passions / 25

The Diagnosis and Cure of the Soul's Errors / 71

Interpretation / 109

Index / 133

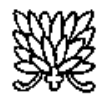





\section{融}

\section{INTRODUCTION}

\section{LIFE OF GALEN*}

Galen's father Nikon was an architect, a philosopher, and a man of ample means-which he transmitted to his son. Galen apparently was always independent of his profession for his livelihood and he could always afford ample material for his experiments. He was born in Pergamum, in Asia Minor, in 130 A.D., then one of the most beautiful Hellenistic cities, an important cultural center with a library second only to that of Alexandria. It is referred to in the Apocalypse of John the Divine as Satan's Throne (Ch. II, 12-17). Per.

"Compiled from C. Singer, The Evolution of Anatomy (New York: Alfred A. Knopl, 1926, 1926); C. Singer, "Galen as a Modern," Proc. Royal Soc. of Med., 17:563-70; and G. Sarton, Galen of Pergamon (Lawrence, Kan.: University of Kangas Press, 1954).

The preparation of the Introduction and Interpretation to these treatises was supported by PHS research grant M 4011 from NIMH, U.S. Public Health Service. 
gamum was both the seat of the greatest cult of Aesculapius in Asia Minor and also of one of the Seven Churches to which John was bidden to write. Galen must have known of the Christian and perhaps of the Jewish community there from his earliest years. Hence, perhaps, his knowledge of their scriptures.

Galen began writing when he was thirteen. He wrote rapidly, easily, and constantly till he died at seventy. At the age of fifteen, his father sent him to attend philosophical lectures. At sixteen, when it was time for him to choose a profession, his father (influenced by a dream) chose medicine for his son.

Galen attended the medical school of his native town from his sixteenth to his nineteenth year, and he lived three years longer at Smyrna, where there was a teacher of anatomy. He completed his medical education with five years of study in Alexandria. From Alexandria, he returned to Pergamum, where he remained for four years as surgeon to the stadium, attending the gladiators and athletes.

At the beginning of the reign of the Stoic emperor Marcus Aurelius, he went to Rome and settled there in practice for three years. Despite, or perhaps because of, his sound training and surgical experience, he had difficulty with his professional colleagues and came to practice rather as physician than surgeon.

When the plague of 165 A.p. broke out in Rome, Galen fled to Pergamum, but returned to Rome in the following year. On his return, he received a command from Marcus Aurelius to join him with his assembled army at Aquileia, close to the modern city of Venice, and to accompany him thence as his personal physician in his expedition against the German tribes. Galen, 
however, managed to escape service in the field, on the plea of looking after the little prince Commodus. He took advantage of the leisure thus afforded to complete his great anatomical works.

Galen retained his position of trust to the end. After the death of Marcus Aurelius in I80 A.D., he became the adviser of Commodus (161-192 A.D.). After the death of Commodus in 192 A.D., Galen was appointed physician to the emperor Septimius Severus (146-2I1 A.D.), who outlived him. His writing remained in standard use throughout the Middle Ages and on into the sixteenth century. He was habitually spoken of as the "Prince of Physicians."

Galen was one of the most versatile and accomplished writers of his age. He composed, it is said, nearly five hundred treatises on various subjects, including logic, ethics, and grammar. In addition to his general, personal, and philosophical writings, he left us therapeutic and clinical treatises as well as anatomico-physiological and pathological works. ${ }^{1}$ of the published works attributed to him, eighty-three are recognized as genuine, nineteen of doubtful authenticity, forty-five are confessedly spurious, nineteen are fragments, and fifteen are notes on the writings of Hippocrates. ${ }^{2}$ Of this abundant corpus, only Galen's treatise On the Nat-

1. C. Singer, The Evolution of Anatomy (New York: Alfred A. Knopf, 1926); C. Singer, "Galen as a Modern," Proc. Royal Soc. Med., 17:568-70.

2. "Galen, Claudius," Encyclopedia Britannica (11th ed.), XI, 398-99. 
ural Faculties, ${ }^{3}$ On Hygiene, ${ }^{4}$ and On Medical Experience $^{5}$ have hitherto been adequately translated into English.

\section{GALEN'S THEORY OF MEDICAL EXPERIENGE}

The essence of Galen's theory of medical experience is embodied in his treatise On Medical Experience. An English translation of its Arabic version was published by Richard Waizer in 1944. The crucial part of the treatise impresses the reader as a kind of dialogue between the empiricist and his opponent, the dogmatist.

The first and main issue at stake in Galen's treatise On Medical Experience is the criterion of the efficacy of a given remedy; but his investigation of the genesis of diseases appears almost equally important. The empiricists (whom Galen occasionally also calls annalists) rely on memory alone. They base all their views, we learn, on experience without logos and place their confidence in such experience. In spite of the almost endless varieties of diseases and diseased individuals, the empiricist tries "to bring the infinite into the category of temporal experience without making use of the logos." Logos obviously is understood to be a generalizing thought, as seen by the following sentence: "If one were to grant them [i.e., the empiricists] that they were able to mention in their books everything that physicians could make use of for purposes of healingalthough this is impossible-no one could remember all

3. A. J. Brock (trans.), On the Natural Faculties ("The Loeb Classical Library" 'London: William Heinemann, Ltd.; and Cam. bridge, Mass.: Harvard University Press, 1947]) .

4. R. Green (trans.), Springfield, Ill.: Charles C Thomas, 1951.

5. Galen on Medical Experience, first edition of the Arabic ver. sion with English translation and Notes by R. Walzer (London, New York, and Toronto: Oxford University Press, 1944). 
these things without having some generalization on which to rely, and without all these things being united by some single thing in which they are all alike." 6 Generalizations are conclusions reached after certain premisses have been made, these premisses being of an experiential nature; but the conclusions themselves are not experiential, but logical, in nature. Logos is also defined by Galen as "the conclusion from the visible to the invisible."7

It is not sufficient, however, the empiricist says, to make an observation but once, nor only a few times, you must make it "very many times." 8

The first objection made to this assumption by his opponent is of a more technical nature. It is not possible, the dogmatist replies, to make the same observation very many times, for the simple reason that diseases, even if seen repeatedly by the same observer, are subject to endless variations, not only in the number of symptoms, but above all in their order. It is the determined place assigned to each symptom within the sequence of all of them which gives to disease its "consistency."

The second objection made by the dogmatist to the empiricist implies a theory of memory. We cannot remember an endless number of isolated observations, regardless of their actual importance and contribution to a given end result. In fact, we have to test all of

6. Ibid., p. 101.

7. Ibid., p. 104.

8. The sect of the Empiricists called the process of a few observations "imitative experience," and that of many observations a "theorem." See K. Deichgräber, Die griechische Empirikerschule (Berlin: Weidmannsche Buchhandlung, 1930), p. 295. 
them as to their "usefulness" and may then have to eliminate some. The basic principle used for this differentiation is causal thought, which thus emerges as an organizing principle of memory and history. The empiricist's neglect of the investigation of causes, his tendency to consider all phenomena on the same level indiscriminately, deprives him of the advantage of distinguishing between essential and accidental onesi.e., between salient causes and simple "concomitants."

In terms of modern medicine, the empiricist does not reach beyond the simple post hoc, and never attains a propter hoc. In cases of perplexity, the empiricist turns to the method of analogies-i.e., the transference from one thing to another of a similar nature. By this is meant the use of the same remedy found to be efficient in one disease for another disease resembling the first one, or the use of the same remedy found efficient when applied to one part of the body for the application to another part. Finally, the use of one remedy may suggest that of a similar one.

The dogmatist does not consider the number of symptoms as sufficient criteria of a given disease, nor does the nature of symptoms by themselves constitute a significant characteristic. Referring to Asclepiades in his treatise "On Medical Experience," Galen distinguished "prognostical" symptoms, which precede the disease, diagnostical ones, which appear along with it, and therapeutical symptoms, which follow the disease. In his book On the Best Sect, Galen analyzed the symptoms from their therapeutical implications. There are no two cases in which symptoms are identical as to type, number, intensity, and chronological order. Since the days of Hippocrates, prognosis was the main con- 
cern of the ancient physician; the thesis of the chronological significance of symptoms is illustrated in the treatise $O n$ Medical Experience by the different prognostic values of symptoms, identical in nature but different in chronological order. Galen taught that treatment is a kind of symptom-formation, the effect of a given therapeutical procedure that preceded certain occupations and manipulations was thought by him to be different from the effect of the same procedure if it succeeded them. Thus he expressed by the term consistency the chronological place of symptoms as the ultimate criterion of disease. What finally emerges is a most rational doctrine of diseases-since the decisive criterion, namely the order of symptoms or the moment of their appearance, remain purely formal determinants devoid of any perceptive qualities.

The doctrine may be extended by a modern reader to merge into a view of human life. What in this view matters is less the type of experience than the moment at which it is experienced, or, again, the place it occupies in the chronological order of all experiences. Thus originates the scheme of an ideal life and evolution in which everything appears at the right moment, and in which nothing is postponed or prevented from coming into being and growing.

"There is no standard by which a thing may be judged as having been seen very many times," we read further in Galen's treatise On Medical Experience.9 The number of identical observations, which the empiricist considers to be conclusive, is reached "solely

9. P. 96 . 
by a usage fixed by himself"-i.e., arbitrarily.10 Moreover, by adding to all previous (but not yet conclusive) observations the last-the decisive one-the empiricist contradicts himself, since he now assigns to an observation made but once an importance previously denied to a single observation. Should it then be true that an ever-increasing number of grains of wheat would never constitute a heap? If the number of houses forming a city remains undetermined, and a single unit added to all previous ones does not make a city what was not a city before, will there ever be a city? When comes the moment where boyhood passes into adoles. cence or manhood into senility? When does one season of the year merge into the other? The empiricist, who has the last word in Galen's treatise, confesses his ignoramus. He does not know why an observation made very many times finally becomes reliable or "technical." He simply refers to common sense, evidence, and experience; but this may leave the question unsettled. Here is a solution.

Heaps, mountains, armies, nations, cities, boyhood, and manhood are concepts, though, of course, stimulated by perceptible material. But it is senseless to raise the question of the beginning or the end of a concept. One cannot pass from one member of a series of isolated perceptible phenomena to a concept valid for the next one. One cannot reach the conceptual whole by spelling-out its perceptible constituents, one after the other. In fact, when passing from single units to the whole, we pass from individualizing to generalizing thought-i.e., from one method of thought to another entirely different one.

I0. Ibid., p. 96. 
We may now resume the problem of the endless variations of diseases and symptoms. If disease in one person is never identical with disease in another, how can there be "diagnosis"? How is it possible to relate the multiplicity of symptoms to a single person as opposed to admitting of as many diseased individuals or diseases as there are differences in symptomatology and their circumstances? The problem is of greatest importance to anyone interested in theory of experience, in medicine or any other field. The solution is hidden in sentences like these: The dogmatists assert "that by means of the logos they can bring into unity things which are utterly opposed to each other."1t But again, as I have observed on a previous occasion,12 the unity here stressed is a purely conceptual one. The conclusion that the individual, too, conceived of as a center of thought and action, is a conceptual unity may seem provocative. The unity of the individual, however, does not exist by itself in a passive way. It is not a finished text we have only to read: we have to construct it again and again. Here are the sources and criteria of conscious life. But here is also the crucial point of division between the two schools of thought that oppose each other today as they did 2,000 years ago. While the empiricist is convinced that he can borrow all his knowledge from perceptual experience, "recognizing nothing except that which can be ascertained by the senses alone, with the help of observation and retention

\section{Ibid., p. 131.}

12. W. Riese, The Conceplion of Disease, Its History, Its Versions and Its Nature (New York: Philosophical Library, 1953), pp. 86-92. 
in the memory," 13 the dogmatist passes "from the visible to the invisible"; not satisfied with plain observation, he inquires into the function-disturbed or not-and into the "nature" of disease. This may be called the logical structure of reality. That there are "many diverse views on the matter" 14 will not discourage the dogmatist and his twentieth-century follower from trying to substitute law for chance, unity of thought for the diversity of endless and accidental observations-goals which they are unable to attain unless these unrelated views are systematized and ordered.

\section{HIPPOCRATISM AND GALENISM}

To past generations, the history of medicine repeatedly reflected as its major theme a struggle between the Hippocratists and the Galenists. The apparently irreconcilable discrepancy of the general views held by both schools of medical thought was embodied in significant antithetic terms, ascribing to the Hippocratists synthetical, observational, and deductive thought; and to the Galenists analytical, experimental, and inductive thought. The discrepancy, however, should not be overstressed. In fact, constituents of both systems of medical thought can be found in either school.

True, Hippocratism reveals its synthetical nature, first, by the negative criterion of its relative negligence of anatomy, which aims at dissection and decomposition, thus, at analysis; and secondly, by the basic Hippocratic idea of the "physis" or healing power of nature, suggesting to the medical historian an anticipa-

19. Galen on Medical Experience, p. 152.

14. Ibid., p. 199. 
tion of vitalism-indeed one of the most significant products of synthetical medical thought-which conveys the conception of a strictly autonomous and nonmaterial character of life and its various manifestations in health and disease.

To understand the antithesis of synthetic medical thought, one simply has to consider the titles of two of the major writings of Galen: De locis affectis and De usu par. tium corporis humani. The emphasis on structural and functional decomposition is implied in them. But, in support of Galen is the Hippocratic description of the signs of imminent death-facies hippocratica-a masterpiece of observation made by steps and according to discriminative selection, and thus, by analytical thought. Is not the same true for the Hippocratic case histories, still readable and instructive to the twentieth-century physician trained in analytical thought? Conversely, Galen displayed a strong sythetical element in his recurrent admiration for the Creator's wisdom and foresight in the usefulness of the perfect adjustment of the anatomical structures to the purposes they served. Again, did Galen not adopt Aristotle's classification of causes, which comprise the "final cause,"-the end for which a structure or a life process comes into being-and does this not imply synthetical rather than analytical thought?

Perhaps the most significant antithesis was drawn between the purely observational nature of Hippocratism and the experimental character of Galenism. In the light of this antithesis, the latter, rather unexpectedly, would appear to anticipate modern science, while it was precisely Galenism that for centuries sponsored the most sterile discussions and scholastic inter- 
pretations of texts at the expense of observation and experimentation.

The concept of therapeutic indication sprang from Hippocratic thought, more specifically from the teaching of the dogmatists; but does indication not imply observation, repeated at will and according to a preconceived idea, thus, does indication not imply experimental thought? Medical history lists the name of Philippe Pinel among the relatively few eminent, modern Hippocratists, but the French alienist defined experimental medicine as faithful and repeated observationand identified it with Hippoctatic medicine.15 Was Galen, who indefatigably acknowledged his debt to the father of medicine, less observational in his clinical approach because he was the first to perform animal experiments successfully on the spinal cord? Are his descriptive analyses of pain and malingery not masterpieces of observation?

Hippocratism has also been opposed to Galenism as deductive thought is opposed to inductive thought. The Hippocratic linkage of man, the microcosm, with the universe or macrocosm, which is his ultimate original; next, the Hippocratic interpretation of all diseases as both divine and human; and finally, the emphasis on biography reflecting the whole of an individual's existence-all these ideas lend sufficient support to the

15. "Experimental medicine ... means to observe carefully, faithfully and repeatedly, to list the general and individual results, to consider the individual constitution, influence of the seasons, life period, etc. This is Hippocratic medicine."-Nosographie philosophique (Paris: J. A. Brosson, 1810), pp. lxxiii-lxxlv. Translated by Walther Riese. 
qualification of Hippocratism as deductive in design. Galen, on the other hand, was the first to introduce regional diagnosis, as well as the term and concept of "symptom" or disordered function (functio laesa)understood to be the vital manifestation of a fragment of the organism.

"I always try," Galen said, "to discover the region affected primarily or secondarily and responsible for the disordered function. As soon as I feel certain," he concluded, "to have found this region, I try to discover the nature of the disorder (diathesis); I derive my indication from both these concepts, considering not only the type of the remedy and its dosage but also the age of the patient, his constitution, the season, place, and all of the Hippocratic criteria." (These diagnostic rules are to be found in the tenth chapter of the second book of Galen's De optima secta, dedicated to Thrasybolus).

Thus was outlined by Galen a strictly inductive medical thought, leading from special indications to a general plan of treatment. But in spite of these lines of demarcation, Hippocratism developed a natural etiology, in which each single term was assigned its proper place and decisive role in the natural history of diseases. Hippocratism also developed a natural prognosis, in which final judgment of the presumable outcome was reached by listing the most minute details of the patient's appearance and behavior-thus, by inducing the general from the particular. Conversely, Galenism borrowed from the Greek philosophers the general idea of health as a state of equilibrium of the four cardinal fluids (eucrasia) and that of disease as their faulty ad- 
mixture (dyscrasia). Evidently, this physiology was a strictly deductive one.16

\section{GALEN'S ANATOMICAL RESEARCHES}

Galen's anatomy was, for centuries, the standard, but was in many ways inaccurate and this, in addition to technical imperfections and inexactitudes, because it was based upon dissection of animals only. Neuburger reports that Galen only twice obtained, through accident, possession of a human skeleton, once in the case of a corpse washed out of its grave by a river in tlood, the second body being that of an executed robber.17 Permission to dissect the bodies of enemies killed in battle was of very little value to science, since the technically ill-equipped surgeons attached to the Roman army were not in a position to derive much advantage therefrom. Galen dissected chiefly the anthropoid apes, bears, swine, ungulates, ruminants, an elephant, birds, fishes, and snakes.

The renovator of human anatomy was Andreas Vesalius (1514-1564). But it was Paracelsus (14931541), another great physician of the Renaissance period, who challenged and violently attacked the whole of Galen's teaching and practice.

\section{GALEN'S PHYSIOLOGICAL SYSTEM}

In his doctrine of the seat of the soul, Galen remained

16. W. Riese, "The Legacy of Ancient Medicine: Hippocratism and Galenism," J. Siudent Am. Med. Assn. (January and February, 1955) .

17. M. Neuburger, History of Medicine, trans. Ennest Playfair (London: Henry Frowde, Hodder \& Stoughton for Oxford University Press, 1910). 
faithful to Plato, whose views he elaborated and reshaped. The three Platonic souls of man recurred in Galen's doctrine as three types of pneuma or spirit.

The pneuma was made by a famous Greek school of medical thought a basic principle of life, instrumental in the interrelation of mind and body, generation and growth. The semantic developments of the Greek word pneuma, of the Latin spiritus, and of the English spirit indicate the same passage from the idea of air and wind, to breath (breathed air), to spirit, soul, and inspiration. 18

The Stoics believed in a general world-pneuma, or world-spirit, which we all share during life, manifesting it by our breathing. At our death, when we cease to breathe, our share passes to rejoin the general worldspirit or anima mundi from whence it was first drawn.19

Honigmann, a most eminent medical historian, identified the basic tenet of the pneumatists, according to which life depends on a foreign agent contained in the air, with a fundamental and ever-lasting principle of physiology. ${ }^{20}$ Sarton, in the same vein, wrote

According to Galen, there are three fundamental members in the body, the lowest being the liver, then the heart, and uppermost the brain. Each of these members is dominated by a special pneuma or spirit. The liver is dominated by the natural or physical spirit (pneuma physicon); a vapor rising from the blood, it controls the

18. G. Sarton, Galen of Pergamon ("Logan Clendening Lectures on the History and Philosophy of Medicine," Ser. 3 [Lawrence, Kan.: University of Kansas Press, 1954])

19. C. Singer, "Galen as a Modern"; Singer, Evolution of Anatomy.

20. G. Honigmann, Geschichtliche Entwicklung der Medizin (München: J. F. Lehmanns Verlag, 1925). 
functions of nutrition, growth, and reproduction. The lord of the heart is the vital spirit (pneuma zotikon); it is the physical spirit transmitted in the veins and transformed in the heart by mixture with the inspired air (the air breathed in); it regulates the vital functions, conveying heat and life through the arteries. This vital spirit is submitted to a second transformation or distillation in the brain and becomes the animal or psychical spirit (pnetma psychicon), regulating the brain, nerves, feelings, etc. 21

Galen also made observational, experimental, and clinical contributions to cerebral localization, and these contributions mark the truly modern elements in Galenism.

He learned from his dissection experiments that the nerves conveying voluntary motor power to the parts below the neck originate from the spinal cord to which sensation and voluntary movement are transmitted from the brain. He made the most remarkable observation that total transection of the spinal cord deprives all parts below the level of the lesion of their sensations and their movements. Semisections, he added, paralyze the ipsilateral parts below the level of the brain. Galen was even in full possession of the knowledge of two different sets of nerve roots, sensory and motor. He did not distinguish between ventral and dorsal roots of the spinal cord; nor did he offer experimental proof of their different functions. This knowledge was not gained

\section{G. Sarton, Galen of Pergamon.}

22. C. Bell, The Nervous System of the Human Body (Washington, D.C.: Duff Green for the Register and Library of Medical and Chirurgical Science, 1833), pp. 6-15. 
until the discoveries made by Sir Charles Bell22 and Francois Magendre ${ }^{23}$ in the early nineteenth century. ${ }^{24}$

To the brain, Galen assigned the role of presiding over sensation and voluntary motion. He called apoplexy that condition in which all of the nerves are deprived of their sensory and their motor powers at the same time. If apoplexy affects but one half of the body (hemiplegia), one member, or only one part of a member, he called it paralysis. He also stated that in those cases in which the facial muscles were paralyzed with the rest of the body, the lesion was in the brain, while it was in the spinal cord if the facial muscles were spared. He applied the same reasoning to convulsions and their regional causes, anticipating the interpretation made by the eminent nineteenth-century clinician, $J$. Hughlings Jackson, according to whom convulsion is the mobile counterpart of hemiplegia. Above all, Galen knew that the involvement of psychic functions would indicate a cerebral site of the lesion. ${ }^{25}$

\section{GALEN-PAGAN NATURALIST}

Galen was the first known, eminent physician to take on active interest in matters political and religious. Medical history lists a number of famous men who engaged in the public affairs of their day. Sydenham, the "British Hippocrates," took an active part in the English Revolution on the side of the parliament; Pinel,

29. F. Magendie, An Elementary Treatise on Human Physiology (New York: Harper \& Bros., 1848).

24. Singer, Evolution of Anatomy; and Singer, "Galen as a Modern."

25. W. Riese, History of Neurology (New York: M.D. Publications, Inc., 1959). 
father of modern psychiatry, son of the French Revolution, witnessed in full military dress, as a member of the national guard, the execution of the king and was shocked. Benjamin Rush, one of the signers of the Declaration of Independence, advanced medical reform in the Revolutionary army. Rudolf Virchow, founder of modern pathology, had to pass through precarious days because of his sympathy with the revolutionary ideas in the Germany of the $1840^{\prime}$ s. In the case of Galen, the topic is particularly attractive, since the Roman physician's polemic attitude toward contemporary religious tendencies, Christian and Jewish, was intimately bound up with medical matters.

Quite recently, Galen's attitude towards Jews and Christians was made the subject of a thorough analysis based on historical sources:

Galen was born six years before the final abortive Jewish revolt under Hadrian which decided the deliberate withdrawal of Judaism from Graeco-Roman civilization; the Jewish leaders now concentrated exclusively, from motives of self-preservation, on the Hebrew and Aramaic elements in their tradition. Thus, it came about that, toward the end of Galen's life, the Jews and their special characteristics were less in the public eye than they had been in the Flavian period and at the second century. Christianity, on the other hand, had emerged from obscurity, and was no longer considered merely a barbarous superstition, and the period of Commodus gave a man of Galen's standing increasing opportunities for acquaintance with educated Christians.

The following passage is to be found in the eleventh book of Galen's anatomical work $D e$ usu partium: 
It is precisely this point in which our own opinion and that of Plato and the other Greeks who follow the right method in natural science differs from the position taken up by Moses. For the latter it seems enough to say that God simply willed the arrangement of matter and it was presently arranged in due order; for he believes everything to be possible with God, even should He wish to make a bull or a horse out of ashes. We however do not hold this; we say that certain things are impossible by nature and that God does not even attempt such things at all, but that he chooses the best out of the possibilities of becoming. We say therefore that since it was better that the eyelashes should always be equal in length and number, it was not that $\mathrm{He}$ just willed and they were instantly there; for even if $\mathbf{H e}$ should just will numberless times, they would never come into being in this manner out of a soft skin; and, in particular, it was altogether impossible for them to stand erect unless fixed on something hard. We say thus that God is the cause both of the choice of the best in the products of creation themselves and of the selection of the matter. For since it was required, first that the eyelashes should stand erect and secondly that they should be kept equal in length and number, He planted them firmly in a cartilaginous body. If $\mathrm{He}$ had planted them in a soft and fleshy substance He would have suffered a worse failure not only than Moses but also than a bad general who plants a wall or a camp in marshy ground. . . .26

The passage implies a teleological interpretation of organisms, which the Pergamese physician believed to be built in such a way that all parts serve their purposes-that is, their functions-in the best possible man.

26. This quotation and the one preceding it have been taken from $\mathrm{R}$. Walzer, Galen on Jews and Christians (London: Geoffrey Cumberlege for Oxford University Press, 1949), pp. 9, 12. 
ner. Thus was recognized Aristotle's "final cause." Galen's writings are endless testimonies of their author's admiration and veneration of the divine design of man's structures and functions. Thus was restored, to some extent, the greatness of the divine architect, who emerged somewhat diminished from the conclusion according to which God cannot achieve things impossible by nature. A thousand years later, the Jewish physician and philosopher, Maïmonides, took up the challenge by affirming that the miracle is only possible in a created world and that, to be precise, the idea of creation was foreign to the thought that had shaped Galen's mind.27 It was the recognition of the purposefulness and perfection of the human frame, which, according to Charles Singer, made Galen acceptable to the Church as an uncontested authority in medical matters for 1,500 years. In fact, traces of Galenism can be found in medical writings and documents up to the middle of the nineteenth century. It is no exaggeration to say that a major part of medical history was written in terms of Galenism, which was, in itself, deeply rooted in the teachings of Aristotle.

\section{GALEN'S MORAL THOUGHT}

The two treatises by Galen in this volume, in their first English versions, present the "prince of Physicians" in two lesser known and studied areas of his prolific activities: moral philosophy and psychotherapy. Unlike his much admired model, Hippocrates, Galen

27. W. Riese, "La Pensée morale de Maümonide, interprétée par les 'Huit Chapitres," Revue d'Histoire de la Medecine Hebraïque, 14* année, No. 54 (1961) , 149-53. 
did not outline a code of medical ethics. But his brilliant comment on a significant passage of the sixth book of the Hippocratic treatise Of the Epidemics can be considered as a fragment on medical etiquette. A French version and analysis have been published recently by Bourgey and myself. ${ }^{28}$ Galen's comment contains also a first (though sketchy) design of an esthetics of alimentation and, above all, a fragment on psychotherapy.

In my interpretation of the two Galenic treatises, I also refer to my lecture on Galen's moral thought, ${ }^{29}$ delivered in 1960 to the Sociéte Moreau de Tours (Paris) and published by the Revue Philosophique. Though Galen's moral thought denied neither its Platonic nor (above all) its Aristotelian heritage, the great Pergamese author emerges primarily as a Stoic from those of his writings in which he deals with problems of human conduct. But as in the religious matter discussed above, his moral thought carried a strongly naturalistic component. The two treatises here translated by Harkins and analyzed by me continue and complete this lesser known picture of one of the greatest physicians of the ancient world.

WALTHER RIESE

28. L. Bourgey and W. Riese, "Les Gracieusetés à l'égard des malades (Commentaire de Galien sur épidémiés, VI, section 4 , division 7)," Revue philosophique de la France et de l'etranger, 150:145-62.

29. W. Riese, "La Pensée morale de Galien," Revue philosophique, scheduled for publication in October, 1963. 



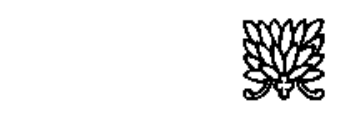

\section{TRANSLATOR'S PREFACE}

This translation of the two treatises of Galen, $O n$ the Passions of the Soul and On the Errors of the Soul, is based, with the kind permission of the Teubner Publishing Company of Stuttgart, Germany, on the text of Wilko de Boer, which appears in the fifth volume of the Corpus Medicorum Graecorum (Leipzig and Berlin, 1937). This text rests primarily on the Laurentian manuscript (plut. 74, 3) which is quite corrupt but vastly superior to the manuscript used for the Aldine text of 1525, the editio princeps, which is basic to all subsequent editions until the edition of Marquardt (Leipzig, 1884). Although Marquardt's text is an improvement on its predecessors because its editor had access to the Laurentian manuscript, his edition is marred by flights of conjecture whereby he has often avoided textual problems. De Boer has restored, for ex- 
ample, some 1,100 words which Marquardt had bracketed as intrusions.

Hence, De Boer's critical text is, in some ways, a new and different edition of these treatises, since it rests on the Laurentian manuscript which had never before been properly exploited and which belongs to a different family from that to which the Aldine manuscript belongs. The present translation, therefore, is also new and different, not only because it is the first translation of these treatises into English, but also because it rests as faithfully as possible on De Boer's critical edition.

Textual lacunae have either been left as such in the translation or have been supplied from the editors' conjectures recorded in De Boer's critical apparatus; in all cases, they have been marked by angular brackets. Occasional brief additions made by the translator for the sake of clarity are distinguished from the text proper by square brackets. Most references to Galen's other works are made by volume and page to Kuehn's text of the Opera Omnia (Leipzig, 1825), since the new Corpus Medicorum Graecorum is still incomplete. References to Galeni de placitis Hippocratis et Platonis are made to Mueller's edition (Leipzig, 1874).

The translator is indebted to his colleagues at Xavier University, C. Leslie Howard and Robert J. Murray, for their suggestions as to the meaning of several vexing passages.

Paul W. Harkins 


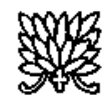

The Diagnosis and Cure of the Soul's Passions

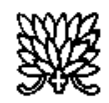



The Diagnosis and Cure of the Soul's Passions ${ }^{1}$

You proposed a question about the treatise of Antonius, the Epicurean, On Guarding One's Passions.2 $I$ answered your question, but since you are now asking to have my reply in the form of a commentary, I shall do so and herewith $I$ begin.

Surely it would have been best for Antonius himself to have told us clearly what meaning he wishes to convey by the term "guarding"; as far as one could conjecture from what he says in the course of his book, I think he means either a watchfulness, or a diagnosis, or, in addition, a correction. But, as you know, he was manifestly indiscriminate and vague in his expression. Hence we must not expect to understand

1. For the title see Galen, Opera Omnia, ed. C. Kuehn (20 vols; Leipzig: Teubner, 1821-33), XIX, p. 45; and XII, p. 335.

2. See E. Zeller, Die Philosophie der Griechen (3 vols. in 6; Leipzig: O. R. Reisland, 1908-22), III, Part 1, P. 389, n. 3. 
many of the things he said; at best we must expect to guess at his meaning. At one time he will seem to be urging us to consider how we ourselves are falling into many errors just as others do, and at another time, how a man may recognize each of his errors, and again, in addition to these considerations, how a man may withdraw himself from his errors. This last seems to me to be the object of his whole discourse, since neither of the preceding considerations has any point unless referred to this end.

But he should have (revised what he wrote), especially when distinguishing between passions and errors. For sometimes his discourse seems to concern the passions alone, often it seems to concern errors, and there are times when you will think he is discussing both. But as you know, I started by making this very distinction when I said that error arises from a false opinion, but passion from an irrational power within us which refuses to obey reason; commonly both are called errors in a more generic sense. ${ }^{3}$ Therefore we say that the licentious man, and the man who acts in anger, and the man who believes slander are all in error.

Chrysippus ${ }^{4}$ and many other philosophers have written books on curing the passions of the soul; Aristotle and his followers also discussed (this question), as did Plato ${ }^{5}$ before them. It would have been better for you to learn these matters from those men, even as I did. But since you bid me so, in this first discourse I shall dis-

3. See Galen, De placitis Hippocratis et Platonis (Leipzig: Teubner, 1874), pp. 341, 9 ff.; 342, 11 ff; 367, 10; 407, $14 \mathrm{ft}$.

4. See H. von Arnim, Stoicorum veterum fragmenta (4 vols. in 2; Leipzig: Teubner, I903-24), III, 46I, Pp. 112.13.

5. See Galen, De placitis Hippocratis et Platonis, pp. 401, $7 \mathrm{ff}$.; $436,7 \mathrm{ff}$.; $476,15 \mathrm{ff}$. 
cuss briefly all the main points and in the order in which you heard them when you inquired about the book written by Antonius.

\section{II}

It is likely that we do err even if we ourselves should think that we do not, and we can infer this from what follows. We see that all men suppose that they themselves are altogether without fault or that their errors are few and mild and at great intervals. This happens especially in the case of those who, in the eyes of other men, err the most. I certainly have strong proof for this if I have proof for anything. I have seen that those men who leave to others the task of declaring what kind of men they are fall into few errors, but I have seen that those men who suppose that they are excellent and who do not entrust this decision to others are the ones who fall most frequently into the gravest errors. When I was a young man, I thought that the Pythian dictum to "know thyself" was held in praise without good reason because it did not enjoin some great action. In later life, I discovered that this dictum was justly lauded because only the wisest man could know himself with accuracy. No other man could do this, although one man might have better or worse knowledge of himself than another man.

In the whole of life and in the individual arts, it is usual for any man to recognize outstanding superiority and differences in things, but only those who are prudent men and skilled craftsmen can recognize slight superiority and differences. The same holds good in the matter of errors and passions. Whenever a man becomes violently angry over little things and bites and kicks his 
servants, you are sure that this man is in a state of passion. The same is true in the case of those who spend their time in drinking to excess, with prostitutes, and in carousing. But when the soul is moderately upset over a great financial loss or a disgrace, it is no longer equally obvious whether this condition belongs to the genus of passions, just as it is not quite certain that the man who eats cakes rather greedily is acting from passion. But even these things become clear to the man who has trained his soul beforehand and has discovered which of his passions need correction, even if (failure) to avoid them is no great defect because they are small.

Therefore, whoever wishes to be good and noble must consider that he cannot but fail to recognize many of his own errors. I can tell him how he might discover them all, just as I have discovered them. But since this book can come into the hands of others, I remain silent and I am not yet telling my method; I want those men to exert themselves, too, so that they may discover a way to know their own errors before $I$ tell them. Just as, therefore, I asked you to speak to me and remained silent until you said what seemed best to you, I shall pursue the same course now, after I have exhorted you who are engaged in reading this treatise to look for the very point therein set forth, namely, how a man may be able to recognize that he is in error.

As Aesop says, we have two sacks suspended from our necks; the one in front is filled with the faults of others; the one behind is filled with our own. ${ }^{6}$ This is the

6. See Fables, ed. C. Halm (Leipzig: Teubner, 1889), p. 359; and also Babrius, Fables, ed. $O$. Crusius (Leipzig: Teubner, 1897), 66, pp. 59-60. 
reason why we see the faults of others but remain blind to those which concern ourselves. All men admit the truth of this and, furthermore, Plato gives the reason for it. ${ }^{7}$ He says that the lover is blind in the case of the object of his love. If, therefore, each of us loves himself most of all, he must be blind in his own case. How, then, will he see his own evils? And how will he know when he is in error? Both Aesop's fable and Plato's maxim seem to demonstrate to us that the discovery of one's own errors is far beyond our hopes. For unless a man can separate himself from self-love, the lover must be blind in the case of the thing he loves.

Even if a man should make, by himself, as extensive an examination into his own errors as he could, he would find it difficult to discover them. Hence, I would not expect him who reads this book to consider, by himself, how to discover his own errors. Moreover, I am declaring my opinion with two purposes in mind: if someone by his own efforts should find some other way, by taking my method in addition to his own, he will be helped all the more because he has found not one but two ways to save himself; if he does not have a way of his own, he will be helped by the continuous use of mine until he finds another and a better way. With this preface, it is time for me to state what my way is.

\section{III}

Since errors come from false opinion while the passions arise by an irrational impulse, ${ }^{8}$ I thought the first

7. Laws, 731 .

8. See above, p. 28, and n. 3. 
step was for a man to free himself from his passions; for these passions are probably the reason why we fall into false opinions. And there are passions of the soul which everybody knows: anger, wrath, fear, grief, envy, and violent lust. In my opinion, excessive vehemence in loving or hating anything is also a passion; I think the saying "moderation is best"9 is correct, since no immoderate action is good.

How, then, could a man cut out these passions if he did not first know that he had them? But as we said, it is impossible to know them, since we love ourselves to excess. Even if this saying will not permit you to judge yourself, it does allow that you can judge others whom you neither love nor hate. Whenever you hear anyone in town being praised by many because he flatters no man, associate with that man and judge from your own experience whether he is the sort of man they say he is. First, if you see him going continually to the homes of the wealthy, the powerful, or even monarchs, be sure that you have heard falsely that this man always speaks the truth, for such adulation leads to lies. Second, be equally sure that his reputation is false if you see him greeting these people by name, visiting them, and even dining with them. Whoever has chosen such a life, not only does not speak the truth, but he is wholly evil, because he loves some or all of the following: wealth, rule, honors, reputation.

When a man does not greet the powerful and wealthy by name, when he does not visit them, when he does not dine with them, when he lives a disciplined life,

9. A dictum of Cleobulus; see Stobaeus, Anthologium, ed. C. Wachsmuth and $O$. Hense (5 vols.; Berlin: Weidmann, 18841912), III, i. 172, p. I12. 
expect that man to speak the truth; try, too, to come to a deeper knowledge of what kind of man he is (and this comes about through long association). If you find such a man, summon him and talk with him one day in private; ask him to reveal straightway whatever of the above-mentioned passions he may see in you. Tell him you will be most grateful for this service and that you will look on him as your deliverer more than if he had saved you from an illness of the body. Have him promise to reveal it whenever he sees you affected by any of the passions I mentioned.

If, after several days, although he has obviously been spending time with you, he tells you nothing, reproach him and again urge him, still more earnestly than before, to reveal immediately whatever he sees you doing as the result of passion. If he tells you that he has said nothing because he has seen you commit no passionate act during this time, do not immediately believe him, nor think that you have suddenly become free from fault, but consider that the truth is one or the other of the following. First, the friend whom you have summoned has either been negligent and has not paid attention to you, or he remains silent because he is afraid to reproach you, or because he does not wish to be hated, knowing as he does that it is usual, as I might say, with all men to hate those who speak the truth. Second, if he has not remained silent for these reasons, perhaps he is unwilling to help you and says nothing for this or some other reason which we cannot find it in ourselves to praise.

If you will now believe me that it is impossible for you to have committed no fault, you will praise (me) hereafter when you see that every day all men fall into 
countless errors and do countless things in passion be. cause they do not understand themselves. Do not, therefore, consider that you are something else and not a human being. But you do judge that you are something other than a human being if you mislead yourself into believing that you have done nothing but good actions for a whole day, much less for a whole month.

If your own choice or some evil disposition has made you disputatious, or if you are naturally disposed to quarrel, perhaps you will rebut the argument I proposed before by contending that wise men are something more than human beings. But compare your argument with mine, which was twofold: first, that only the wise man is entirely free from fault; second, in addition to the foregoing, if the wise man is free from fault, neither is he a human being in this respect. This is why you hear the philosophers of old saying that to be wise is to become like God.10 But, surely, you would never suddenly come to resemble God. When those who have spent their entire lives training themselves to be free from emotion do not believe that they have perfectly acquired this goal, you should be all the more convinced that you are not free from emotion since you have never devoted yourself to this training.

Therefore, you must not believe the man who tells you he has seen you do nothing in passion; consider that he says this because he is unwilling to help you, or because he chooses not to observe the wrong you do, or because he wishes to make sure that you do not come to hate him. Perhaps, too, he has seen that you could not endure it in the past when someone censured

10. See Plato, Theaetetus, 176b. 
your errors and passions; hence, he naturally remains silent because he does not believe you are telling the truth when you say that you wish to know every wrong action you commit. But if you will remain silent from the first and utter no complaint against him who would correct you and free you from your deeds (of passion), you will find in a very short time thereafter many men who will give you true correction; this will be all the more likely to happen if you show gratitude to your corrector after you have, thanks to him, removed the harm from yourself. You will find a great advantage in considering whether he is right or wrong in censuring you. If you do this continuously because you have really chosen to become a good and noble man, you will be such.

In the very beginning, even if you find on examination that he has brought a charge against you which is insolent and untrue, do not try to persuade yourself that you have done no wrong; but let this be your first rule of conduct, namely, to be steadfast when treated with insolence. Sometime later, when you see that your passions have been put under restraint, you may undertake to defend yourself against your slanderer. But do not make it clear by the bitterness of your reproof and by the contentiousness of your words that you wish to confound him; rather, give evidence that you are acting to improve yourself. Hence, after he has spoken persuasively and contradicted you, you will win him over to a better understanding, or you will find, after a more extensive examination, that he was in the right. So at any rate Zeno, too, deemed that we should act carefully in all things-just as if we were going to answer for it to 
our teachers shortly thereafter. For, according to Zeno, 11 most men are ready to censure their neighbors, even if no one urges them to speak.

However, the man who asks for counsel must neither be wealthy nor possess civil dignity: fear will keep anyone from telling the truth to one in civil office, just as fear of losing their profit will keep flatterers from telling the truth to the rich. Even if there be someone who seems to be telling the truth, these flatterers stand aloof from him. If, therefore, anyone who is either powerful or also rich wishes to become good and noble, he will first have to put aside his power and riches, especially in these times when he will not find a Diogenes who will tell the truth even to a rich man or a monarch.

The rich and powerful, then, will be their own counsellors. But you are not one of the city's wealthy or powerful men. So let all tell you what fault they find with you; be not angry with anyone; consider all, as Zeno said,12 as your teachers. Nor should you pay the same heed to all the things they say to you. Heed most the older men who have lived excellent lives. Who these men of excellent life are, I have pointed out above. ${ }^{13}$ As time goes on, you will understand without their help and realize how great were your former errors; then especially will it be clear that I am telling you the truth when I say that no one is free from passions and errors, not even if he be of the best natural disposition and reared with the best habits, but that everybody slips and does so all the more when he is young.

11. See Arnim, Stoicorum veterum fragmenta, I, 239, p. 56.

12. Ibid.

13. See above, pp. 32-33. 


\section{IV}

For each of us needs almost a lifetime of training to become a perfect man. Indeed, a man must not give up trying to make himself better even if, at the age of fifty, he should see that his soul has suffered damage which is not incurable but which has been left uncorrected. Even if a man of this age should find his body in poor condition, he would not give it over entirely to its poor health, but he would make every effort to make himself more vigorous, even if he could not have the bodily strength of a Hercules. Therefore, let us continue striving to make our souls more perfect, even if we cannot have the soul of a wise man. If from our youth we take thought for our soul, let us have the highest hope that we will one day have even this, namely, the soul of a wise man. If the fact is that we have failed in this, let us see to it that, at least, our soul does not become thoroughly evil-as was the body of Thersites.14 Suppose, when we were coming into existence, we could talk with the one superintending our birth; suppose we were to ask him for the most healthy body and he were to refuse; would we not, at all events, ask him successively for the body which was second, third, or fourth healthiest? If we cannot have the healthy body of Hercules, the body of Achilles is satisfactory; if we cannot have the health of Achilles, then let us have that of Ajax or Diomede or Agamemnon or Patroclus; if we cannot have any of these, then, at least, let us have the healthy body of some other hero whom we admire. In the same way, then, even if a man

14. For Thersites, see Homer, lliad, ii, 216-I7: "He was the ugliest man who came to Troy; both his legs were bowed and one of them was lame." 
cannot have the most perfect health of soul, I think he would accept being second or third or fourth from the top. Nor is this impossible for one who has made up his mind, if he has been in continuous training over a considerable period of time.

When I was still a youth and pursuing this training, I watched a man eagerly trying to open a door. When things did not work out as he would have them, I saw him bite the key, kick the door, blaspheme, glare wildly like a madman, and all but foam at the mouth like a wild boar. When I saw this, I conceived such a hatred for anger that I was never thereafter seen behaving in an unseemly manner because of it. At present this will be enough to keep you from blaspheming, from kicking and biting stone and wood,15 from looking wild looks; this will be sufficient motive for you to conceal your anger and to keep it within you. A man cannot free himself from the habit of anger as soon as he resolves to do so, but he can keep in check the unseemly manifestations of his passion. If he will do this frequently, he will then discover that he is less prone to anger than he formerly was. Things which are unimportant or less important will not rouse his wrath; and even if he does become angry over matters which are of great importance his anger will be slight. And he will achieve this result, namely, that at some later date he will become only a little angry over serious matters, if he will follow a practice of mine. When I was a young man I imposed upon myself an injunction which I have observed through my whole life, namely, never to strike any slave of my household with my hand. My

15. See Philodemus, De ira liber, ed. C. Wilke (Leipzig: Teubner, 1914), Pp. xlii-xlìii. 
father practiced this same restraint. Many were the friends he reproved when they had bruised a tendon while striking their slaves in the teeth; 10 he told them that they deserved to have a stroke and die in the fit of passion which had come upon them. They could have waited a little while, he said, and used a rod or whip to inflict as many blows as they wished and to accomplish the act with reflection.

Other men, however, not only (strike) with their fists but kick and gouge out the eyes and stab with a stylus when they happen to have one in their hands. I saw a man, in his anger, strike a slave in the eye with a reed pen. ${ }^{17}$ The Emperor Hadrian, they say, struck one of his slaves in the eye with a stylus; and when he learned that the man had lost his eye because of this wound, he summoned the slave and allowed him to ask for a gift which would be equal to his pain and loss. When the slave who had suffered the loss remained silent, Hadrian again asked him to speak up and ask for whatever he might wish. But he asked for nothing else but another eye. For what gift could match in value the eye which had been destroyed?

I wish to remind you of something which once happened to me, even if $I$ have often spoken about this same incident. When $I$ was returning home from Rome, I traveled together with a friend of mine from Gortyna in Crete. This friend was, in other respects, an estimable person because he was simple, friendly,

16. See Demosthenes, Orationes, eds. S. Butcher and W. Rennie (3 vols.; Oxford: Oxford University Press, 1908), III, xlvii. 38; and Plautus, Comoediae, ed. W. Lindsay (2 vols.; Oxford: Oxford University Press, 1910), II, Rudens, line 710.

17. See Philodemus, loc. cit. 
good, and anything but miserly. But he was so prone to anger that he used to assail his servants with his hands and even sometimes his feet, but far more frequently with a whip or any piece of wood that happened to be handy.

When we were in Corinth, we decided to send all our baggage and all the servants, except two, from Cenchreae to Athens by ship while he would hire a cart for our journey overland by way of Megara. Indeed, when we had passed through Eleusis and were coming to the Thriasian Plain, he asked the servants (who were following the cart) about a piece of luggage, but they could give him no answer. He fell into a rage. Since he had nothing else with which to strike the young men, he picked up a good-sized sword in its scabbard and came down on the heads of both of them with the sword-scabbard and all. Nor did he bring down the flat side (for in this way he would have done no great damage) but struck with the cutting edge of the sword. The blade cut right through the scabbard and inflicted two very serious wounds on the heads of both-for he struck each of them twice. When he saw the blood pouring forth in abundant streams, he left us and quickly went off to Athens on foot for fear that one of the servants might die while he was still present. We got the wounded men safely to Athens.

But my Cretan friend heaped charges on his own head. He took me by the hand and led me to a house; he handed over his whip, stripped off his clothes, and bade me to flog him for what he had done while in the violent grip of his cursed anger-for that is what he called it. When I laughed (and this was a reasonable reaction), he fell on his knees and begged me to do 
what he asked. it was very clear that the more he kept importuning me and asking to be flogged, the more he was making me laugh. When we had wasted enough time in begging and laughing, I promised him that I would flog him if he would himself grant me the one very small thing which I was going to ask. When he did promise, I urged him to pay attention to me while I had a few words to say to him, since this was my request. When he had promised that he would do so, I spoke to him at some length and admonished him that it was necessary to train the irascible element within us. This is the way, obviously, that I flogged him and not in the way he asked. After I had instructed him, I went away.

That friend of mine, then, took thought for himself and in a year he became a much better man. Even if you should not become much better, be satisfied if in the first year you have advanced and shown some small measure of improvement. If you continue to withstand your passion and to soften your anger, you will show more remarkable improvement during the second year; then, if you still continue to take thought for yourself, you will notice a great increase in the dignity of your life in the third year, and after that, in the fourth year, the fifth, and so on. A man does everything, for many years in succession, that he may become a good physician, or public speaker, or grammarian, or geometer. Is it a disgrace for you to toil for a long time that you may one day be a good man?

\section{V}

How, then, does one begin this training? Let us take 
it up again, for there is no harm in saying the same things twice or three times in matters which are most necessary. The beginning is never to use one's own hand in punishing a servant who has done wrong. I once heard that Plato had forgiven one of his servants who had done some wrong; ${ }^{18}$ because $I$ thought his action noble, I acted in the same way throughout my life. So, too, you must exhort yourself never to strike a slave with your own hands, nor to assign the task to another while you are still angry; put it off until the next day. After your wrath has subsided, you will consider with greater prudence how many lashes should be given to the one who has merited the flogging.

Is it not better to be reasonable at first and to postpone inflicting the punishment, even if you have called for the whip, lashed him with your tongue, and threatened never again to forgive him if he be guilty thereafter of similar misdeeds? Surely, it is much better to inflict the punishment when you are no longer boiling with passion and after you are free from your unreasoning rage; fresh reflection will then show you what has to be done. You can see that rage is a madness from the things men do when they are in the grip of rage: they strike and kick and rip their clothes; they shout and glare; they go on and on until, as I said, they become enraged at doors and stones and keys, smashing one thing, biting another, kicking a third. ${ }^{10}$

Perhaps you say that these actions are characteristic of men who are truly mad, whereas the things you do

18. See Diogenes Laertius, Lives of Eminent Philosophers, tr. R. D. Hicks (2 vols.; London: Heinemann, 1925), I, iii. 38-39, PP. 310.12.

19. See Philodemus, De ira, pp. xlii, 39. 
are characteristic of the temperate man. I admit that those who strike their servants with their own hands are not such great sinners as those who bite and kick stones, doors, and keys, but I am convinced that inflicting an incurable injury on a human being is the act either of someone slightly insane or of an irrational, wild animal. Man alone, as compared with other things, has the special gift of reason; if he casts this gift aside and indulges his anger, he is living and acting like a wild animal rather than a man.

Therefore, do not consider him a wise man who only stands acquitted of this very thing, namely, kicking, biting, and stabbing those nearby. Such a man, it is true, is no longer a wild beast, but he is indeed not yet a wise man; he is somewhere between the two. Are you, therefore, content if you no longer are a wild beast? Are you not concerned with becoming a good and noble man? $\mathrm{Or}$, since you are no longer a wild beast, is it not better that you cease to be mad and irrational? If you will never be a slave to anger, if you will always reason things out and do everything you think best after dispassionate consideration, you will be a good and noble man.

How will this come to pass? It will come to pass after you have conferred upon yourself the greatest conceivable honor. If you are the one man who is not prone to anger, does this not prove that you are better than all men? But perhaps you wish to be considered better, although you are not willing really to be betterlike someone who, in reality, is physically sick but is eager to be thought healthy. Do you not think that anger is a sickness of the soul? Or do you think that men of old were wrong when they spoke of grief, 
wrath, anger, lust, fear, and all the passions as diseases of the soul? 20

As I see it, this is by far the better course to follow: first, if a man wishes to keep as free as he can from the passions I mentioned, as soon as he gets up from bed, let him consider for each of his daily tasks whether it is better to live as a slave to his passions or to apply reason to each of them; second, if he wishes to become good and noble, let him seek out someone who will help him by disclosing his every action which is wrong; next, (he must) keep this thought before his mind each day and hour: it is better for him to esteem himself as one of the good and noble, but none of us can succeed in this unless he has someone to point out his every error; moreover, we must consider the one who shows us our every fault as our deliverer and greatest friend.

Furthermore, even if you sometimes think that the charges such a friend lays at your door are false, you should restrain your anger. Why? First, it is possible that he sees better than you do the errors into which you fall, just as it is possible that you see it better than he when he does something wrong. Second, even if at times he is wrong in upbraiding you, you must on that account rouse yourself to a more accurate examination of your actions. But the most important thing is that, after you have decided to esteem yourself as a good and noble man, you see to it that you keep before your mind the ugliness of soul of those who are angry and the beauty of soul of those who are not prone to anger.

A man who has for a long time habitually fallen into error finds it difficult to remove the defilement of

20. See De placitis Hippocratis et Platonis, p. 495, 1 ff. 
the passions from his soul; hence, he must for a long time practice each of the principles that are calculated to make the man who complies with them a good and noble person. For the soul is already full of passions, and, hence, we fail to notice one which is driven from the soul without great effort on our part. Therefore, each of us who wishes to be saved has to understand that (he must) not relax his vigilance for a single hour; we must permit all men to accuse us; we must listen to them in a gentle spirit; 〈we must show) gratitude, not to those who flatter us, but to those who rebuke us.

If you have prepared yourself so well that you are confident that no one who comes to visit you will find you caught in the strong grip of any of the major errors, let the door to your house always stand open and grant your close friends the right to enter at any time. Cutting out any error is difficult for one who is unwilling to try. But if a man determines to do so, it is very easy to get rid of the major errors. With your door ever standing open, as I said, give your close friends the authority to enter at any time. All men who have entered public life try to be moderate in all their actions; you must do the same in your own home. When those men [in public life] have done some wrong and are caught, they are not ashamed of themselves but that others have found them out. But you must be ashamed of yourself and pay special heed to him who says:

Of all things, be most ashamed of yourself.21

If you do this, some day you will be able to tame and

21. See Carmen aureum, ed. E. Diehl, in Anthologia Lyrica (Leipzig: Teubner, 1923), XII, ii. 186. 
calm that power of passion within you which is as irrational as some wild beast. Untamed horses are useless, but horsemen can in a short time make them submissive and manageable. Can you not take and tame this thing which is not some beast from outside yourself but an irrational power within your soul, a dwelling it shares at every moment with your power of reason? Even if you cannot tame it quickly, can you not do so over a longer period of time? It would be a terrible thing if you could not.

My treatise On Moral Character22 told at length how a man might make his soul a very good one; it pointed out that there is no need for him to destroy his soul's strength any more than we would destroy the strength of the horses and dogs which we put to our use. But just as we exercise our horses and dogs in the practice of obedience, we must also cultivate obedience in our soul. That same treatise also made it quite clear to you how you might use the irascible power itself to help you fight against the other power, which the philosophers of old called the concupiscible, ${ }^{23}$ by which we are carried, without thinking, to the pleasures of the body.

When a man's anger makes his behavior unseemly, it is a disgraceful thing to see. It is just as disgraceful when his unseemly behavior is due to erotic desire and gluttony and to drunkenness and luxuriousness in eat-

22. This treatise of Galen has not come down to us. See Galen, Opera Omnia, XIX, p. 45.

23. See De placitis Hippocratis et Platonis, pp. 480, 1-483, 14; Plato, Republic, 440a. By the "Philosophers of old," he means Plato; see De placitis, pp. 405, 14; 658, 11. 
ing, which are actions and passions belonging to the concupiscible power of his soul. Unlike the irascible power, I represented this power as not suited to horses and dogs but befitting the wild boar and goat and any of the wild beasts which cannot be domesticated. And so there is no training for the concupiscible power corresponding to the training afforded by obedience to the irascible part of the soul, but there is a kind of analogy between this obedience and what the ancients called chastisement.

The chastisement of the concupiscible power consists in not furnishing it with the enjoyment of the things it desires. If it does attain to this enjoyment, it becomes great and strong; if it is disciplined and corrected, it becomes small and weak. The result is that the concupiscible power does not follow reason because it is obedient but because it is weak. Surely the same is true with human beings themselves: we see that the worse follow the better either because the inferior men are forced against their wills, as is the case with children and slaves, or because they obey willingly, as do men who are good by nature. And moreover, the ancients24 had a name in common use for those who have not been chastised and disciplined in this very respect: that man, whoever he be, in whom it is clear that the power of reason has failed to discipline the concupiscible power is called an intractable or undisciplined man.

We have in our souls two irrational powers. The one [the irascible,] has for its task to become angry and wrathful on the spot with those who seem to have treated us ill in some way. It is also a function of this

24. See De placitss Hippocratis et Platonis, p. 347, $10 \mathrm{ft}$. 
same power to cherish its wrath for a longer period since the passion of anger is greater in proportion to the length of time it endures. The other irrational power in us [the concupiscible] is the one by which we are carried forward to what appears to be pleasant before we have considered whether it is helpful and good or harmful and bad.

Strive to hold the impetuosity of this power in check before it grows and acquires an unconquerable strength. For then, even if you will to do so, you will not be able to hold it in check; then you will say what I heard a certain lover say-that you wish to stop but that you cannot-then you will call on us for help but in vain, just as that man begged for someone to help him and to cut out his passion. For there are also diseases of the body so intense that they are beyond cure.

Perhaps you have never thought about this. It would be better, then, for you to think now and consider whether I am telling the truth when I say that the concupiscible power often waxes so strong that it hurls us into a love beyond all cure, a love not only for beautiful bodies and sexual pleasures but also for voluptuous eating, gluttony in food and drink, and for lewd, unnatural conduct, or if I am mistaken about these and many of the matters I spoke of before.

Consider that what I said before 25 about anger has also been said about the other diseases of the soul, First, we must not leave the diagnosis of these passions to ourselves but we must entrust it to others; second, we must not leave this task to anyone at all but to older men who are commonly considered to be good and 
noble 26-men to whom we ourselves have given full approval because, on many occasions, we have found them free from these passions. We must further show that we are grateful to these men and not annoyed with them when they mention any of our faults; 27 then, too, a man must remind himself of these things each dayif he does so frequently it will be all the better, but if not frequently, at least let him do so at dawn, before he begins his daily tasks, and toward evening before he is about to rest.28 You may be sure that $I$ have grown accustomed to ponder twice a day the exhortations attributed to Pythagoras-first I read them over, then I recite them aloud.

It is not enough for us to practice self-control over our anger; we must also cleanse ourselves of voluptuous eating, carnal lust, drunkenness, excessive curiosity, and envy. Let someone else keep watch over us to see that we are not seen greedily filling ourselves with food as dogs do, or, as do those who are on fire with a nonintermittent fever, that we do not lift the drink to our lips more greedily than becomes a man of dignity. For hunger is not a fitting reason to fill one's belly greedily and to excess, nor does thirst justify draining the whole cup in a single gulp. A gluttonous appetite for everything in sight is a much less suitable reason for enjoying more than a small piece of pastry or some other dainty tidbit. Moreover, while we are novices in all these matters, we must ask others to watch over us and inform us of any error into which we fall; later on,

26. See above, p. 36 .

27. See above, pp. 34-35.

28. See verses $40 \mathrm{ff}$. of Carmen Aureum (Anthologia lyrica graeca, Vol. II). P. 86. 
let us, without our tutors' help, keep watch over ourselves and be on our guard in order that we may take less to eat than those who are dining with us and that we may keep away from the dainty foods while we eat the healthful foods in moderation.

As time goes on, I would no longer ask you to look at your companions at the table, for it is no great task to eat and drink more temperately than they do; if, however, you have really learned how to judge yourself, consider whether you have lived a life of greater self-discipline yesterday or today. For if you will do this, you will perceive day by day that you are more content to keep away from the things of which I spoke; you will see that you will greatly gladden your soul, if indeed you will be a true lover of temperance. For any man is glad to make progress in that which he loves. Hence it is that we see that drunkards are glad when in drinking they outstrip those with whom they drink; gluttons are happy to surpass those who delight in the abundance of foods; the voluptuary in eating rejoices when he outdoes those who find their joy in cakes, in pots and pans, and in sacks for food. And I have known some men who were conceited about the large number of their sexual exploits.

Just as those men practice and pursue the height of the objects of their zeal, so must we zealously pursue the peak of temperance. If we shall do this, we will not compare ourselves to the undisciplined and intemperate, nor will it be enough to have more self-discipline and temperance than they. First, we will strive to surpass those who earnestly pursue this same virtue of temperance, for such rivalry is very noble; after them, let us strive to surpass ourselves, so that from long-con- 
tinued custom we may enjoy using the foods which are both the most healthful and the easiest to provide as well as the most nourishing. Let us remind ourselves that this is one of the proverbs which is well said: "Choose the life which is best; living with it will make it pleasant."'29

When I asked you to exercise yourself against your anger, you were able to see as a token of the benefit gained that you no longer were becoming angry.30 In the same way, let the fact that you no longer yearn for the things which are most pleasant be a token for you in the matter of temperance. The road to temperance is through self-discipline. It is in this very way that the temperate man holds an advantage over the man who has no command over himself: the temperate man no longer yearns for delicacies of the table, either because of long-standing habit or because of his selfcontrol-as the very name shows, since it is derived from controlling and conquering one's desires. To practice it is toilsome and diffcult, at least at the beginning, but this is the case with every practice of a noble pursuit.

If, therefore, you wish to have either virtue instead of wickedness or peace of soul instead of titillation of the body, you must exercise yourself in the aforementioned manner as you make your way to temperance through self-control. But if you decide either to dishonor virtue or to feel titillation through your whole body, then you must lay this discourse aside. It does not exhort to virtue; but for those who have been won over, it ex-

29. Pythagoras, quoted by Stobaeus, Anthologium, II, i. 29, p. 14; xxix. 99 , p. 659 .

30. See above, pp. $38-39$. 
plains the way in which a man might acquire virtue.

Although my discourse is divided into two parts, namely, how each of us becomes able to know himself, and how each may correct his errors when he has recognized them, I do not propose to speak about the correction, but rather about the recognition of one's own errors. But since it is not possible for beginners to recognize these errors by themselves, we shall appoint others to watch over those who are beginning. These overseers will be themselves well trained and able to recognize the errors and passions from which they have been set free and to see what they still require for perfection.

I shall also say now what I am in the habit of saying on every occasion: in one way, it is the most difficult of all things for a man to know himself; in another, it is the easiest. (For if a man wishes to have a knowledge of his inner self, he must work very hard to obtain it; if he desires only a surface knowledge, this will be his with practically no effort at all. $\rangle^{31}$

\section{VII}

And so, in response to your wish, I set down the sum total of all I have said ${ }^{32}$ and all $I$ am going to say. Although there may be some other way by which a man becomes good and noble, I do not know how to discover it. ${ }^{33}$ Hence, I personally followed this way throughout

31. The text between the angular brackets is mutilated and contains a lacuna. The translation represents what appears to be a conjecture embodied in the Latin translation given in Kuehn's edition of 1825 .

32. See above, pp. 28-29.

33. See above, p. 81 . 
my whole life, and I did not begrudge explaining it to others; in fact, I urged them to change places with me and to instruct me if they knew of some other way to become noble and good. But until we come across some other way, let us busy ourselves with this method which is the usual one for recognizing and curing all diseases of the soul. For obstinacy, love of glory, lust for power are diseases of the soul. Greediness is less harmful than these, but it, too, is, nevertheless, a disease. And what must I say of envy? It is the worst of evils. I call it envy whenever someone is grieved over the success of others. All grief is a disease, and envy is the worst grief, whether we call it a passion or a kind of pain which borders on grief.

But the method of cure which I have mentioned ${ }^{34}$ is in all cases the common one. We must observe what is shameful and to be shunned in the instances of those who are caught in the violent grip of these diseases, for in such men the disgrace is clearly seen. But we must not think that we do not have our share of disgrace because we do not see it in ourselves. The lover is blind with respect to what he loves; 35 the insignificant vices which we overlook in ourselves because of our blindness cannot be overlooked in others because they are so large.

Hence, we must find some mature person who can see these vices and urge him to reveal with frankness all our errors. Next, when he tells us of some fault, let us, first, be immediately grateful to him; then, let us go aside and consider the matter by ourselves; let us cen-

84. See above, pp. $29 \mathrm{ff}$.

35. See Plato, Laws, 781e, and above, pp. 30-31. 
sure ourselves and try to cut away the disease, not only to the point where it is not apparent to others, but so completely as to remove its roots from our soul. For if it is not removed, it will be watered by the wickedness of the other diseases dwelling in the soul and sprout up again. Therefore, we ourselves must pay attention to each of the diseases which we notice in our neighbors to see if any of these ills are in our own soul. For this disease must be cut out while it is still sprouting and before it has become so large as to be incurable.

Most men look with scorn upon all the other diseases of the soul, 36 and so they fail to observe them when they see other men who are affected by them. But no one fails to see clearly that grief is an evil of the soul, just as pain is an evil for the body.

When one of the young men with whom I was quite well acquainted was distressed over a small matter and had noticed this one evening, he came to me at dawn and said that he had been awake all night because of this, until he remembered that $I$ was not as distressed over very important matters as he was over small ones. He wanted to know how I excelled him in this, whether it was the result of practice, or of principles I held, or because I was such by nature. And so I told him the truth. I told him that, in the age of boyhood, nature is in all cases a great factor, as is also imitation of those about us; later on, principles and practice are important influences.

That our individual natures are entirely different we can learn clearly from the children who are brought to our attention. Some of them are always radiant and

36. See above, pp. 3\$- $\$ 4$. 
smiling, others are always sullen and sad; some are ready to laugh at everything, others are ready to weep at the least pretext; some share (all) they have, others hoard everything; some become angry over the smallest things so that they bite and kick and take vengeance on their neighbors with sticks and stones when they think they have been unjustly treated, others are forbearing and mild, neither growing angry nor crying until they have suffered some great injustice. And so Eupolis, the comic poet, represented Aristides the Just as being asked this question:

Through what influence did you become so outstandingly just?

and then showed him replying:

Nature was the strongest factor, but then I lent nature a ready hand. 37

Not only, then, are the natures of the young predisposed to grief but they are also readily inclined to anger and sumptuous eating, passions which I have spoken about at length up to now. Besides the types of young men I have already mentioned, you can see some who are shameless, others who are respectful; some have good memories, others are unmindful and forget; some work hard at their studies while others are careless and lazy; among those who work hard some are ready to rejoice when praised, others blush when their teachers find fault with them, and still others

37. Fragment 91 in T. Kock, Comicorum Atticorum fragmenta (9 vols.; Leipzig: Teubner, 1880-88), I, p. 280. 
are ashamed when they are punished; so also among the lazy, you can see that each one has a different reason for his indolence.

Therefore, all who observe children call some modest and others shameless. In the same way, they call them either ambitious and lovers of beauty and goodness, or say that they are indifferent to honor, beauty, and goodness. They further say they are either cowards or contemptuous of blows; and they put other such names on them according to their natures. In this way, then, we see that some children are naturally truthful or liars and have many other differences of character about which there is now, in all likelihood, no need to speak, because some of these children are very easily educated while others benefit not at all. We must not, on that account, neglect the young, but we must rear them in the best habits. If their nature will accept the advantage of our care, they could become good men. If they should fail to accept this attention, the blame would not be ours.

The education of children in some way closely resembles horticulture. For all his careful attention, the farmer could never make a bramble bush produce a bunch of grapes. To begin with, the nature of the bush does not admit such a perfection. Again, even though vines may in themselves be fruitful, they will produce inferior fruit or none at all if the farmer has neglected them and left them to nature alone. The same is true of animals. If you train a horse, you will have an animal that is useful for many things; but even if at times a bear appears tame, it does not constantly maintain this mild mood, whereas the viper and the scorpion never go so far as to give the appearance of being tame. 


\section{VIII}

I am not qualified to say what kind of nature I had as a boy-to know oneself is a difficult thing for fullgrown men, much less for boys-but I did enjoy the good fortune of having the least irascible, the most just, the most devoted, and kindest of fathers. $38 \mathrm{My}$ mother, however, was so very prone to anger that sometimes she bit her handmaids; she constantly shrieked at my father and fought with him-more than Xanthippe did with Socrates. ${ }^{39}$ When I compared my father's noble deeds with the disgraceful passions of my mother, I decided to embrace and love his deeds and to flee and hate her passions. Just as in these respects $I$ saw the utter difference between my parents, so also did I see it in the fact that my father (seemed) never to be grieved over any loss, whereas my mother was vexed over the smallest things. Surely, you know, too, that children imitate the things in which they take pleasure but that they shun the things on which they look with disgust.

Such, then, was the training I received under my father. After I had completed my fourteenth year, I attended lectures by philosophers from my own citymostly under a Stoic who was a disciple of Philopator, 40 but for a short time, also, under a Platonist, a disciple of Gaius.41 Gaius himself no longer had leisure for teaching because his fellow-citizens forced him to hold public offices, since he alone was, in their

38. See also Galen, XIX, p. 99 (De libris propriis, ch. 21).

39. The ill temper of Socrates' wife, Xanthippe, is prover. bial.

40. See E. Zeller, Die Philosophie der Griechen, III, Part 1, p. 714 .

41. See ibid., p. 832 . 
judgment, just, above the lure of wealth, affable, and gentle. Meanwhile, I studied under another teacher from my home town, a disciple of Aspasius ${ }^{42}$ the Peripatetic, on his return from a long sojourn abroad. After him, I had another teacher from Athens, an Epicurean. For my sake, my father made a close investigation of the lives and doctrines of all these men and went along with me to hear them. But my father's training lay chiefly in the sciences of geometry, arithmetic, architecture, and astronomy. Therefore, since he liked to talk after the fashion of geometrical demonstrations, 〈he believed that) one who taught pother disciplines should $\rangle$ use $\left\langle\right.$ a similar method of presentation.$^{43}$ For this reason, he said that there was no need for my teachers in the liberal disciplines to disagree with one another, just as there was no disagreement among the teachers of old in the aforementioned sciences, of which geometry and arithmetic are the foremost.

He went on to say that I must not be hasty in proclaiming myself a member of one sect, but that I must inquire, learn, and form my judgment about these sects over a considerable period of time. He also maintained that I must strive, now and throughout my life, to pursue those practices which all men praised and which the philosophers agreed must be emulated. He asked me to learn and wax strong while seeking after justice, temperance, fortitude, and prudence. All men

42. See ibid., p. 806.

43. The Greek text is defective. Several emendations seem necessary, but those which have been tried have not been successful. The translator has not attempted to restore the text but to supply the sense of the lacuna by means of the words in angular brackets. It must be noted that the defects of this sentence make the meaning of the following sentence obscure. 
praise these virtures and, even if they themselves are aware that they do not possess any one of them, they strive, at least, to appear in the eyes of other men as brave, temperate, prudent, and just; however, when it comes to grief, they try to be truly free from it, whether they appear so to their neighbors or not. Hence, he told me that I must, above all things, practice this serenity which all men pursue more eagerly than they pursue virtue.

These, I said, were the injunctions $\mathrm{I}$ received from my father, and I have observed them up to the present day. I did not proclaim myself a member of any of those sects of which, with all earnestness, I made a careful examination, but I continued undaunted in the face of day by day occurrences throughout my life, just as I had seen my father do. No loss was enough to cause me grief. I do not know if I would grieve if I should lose all my possessions, for I have never yet experienced such a large loss. My father also accustomed me to look with scorn on glory and honor and to hold only the truth in esteem. But I see many men grieving when they think that someone has dishonored them or because of the loss of money. In a matter of this sort, you would never see me grieving, unless I incurred a loss of money so great that I was no longer able with what was left to take care of my bodily health, or unless I incurred some dishonor such as I see in the case of those who have been deprived of the honor of their seats in the Council. If I should hear that some men find fault with me, I oppose to them those who praise me, and I consider that the desire to have all men praise me is like the desire to possess all things.

Furthermore, I said, I think and I believe you think, 
too, that it is because $I$ have up to the present endured no great suffering that $I$ am perfectly free from pain and grief. It is true that $I$ have neither been deprived of all my possessions nor have I suffered any dishonor. But if an ox or a horse or a slave died, this loss was not enough to cause me grief, because I remembered the counsel given me by my father when he advised me not to grieve over the loss of possessions-as long as what was left was enough to take care of my bodily needs.

This is what he laid down as the basic standard for possessions, namely, not to be hungry, not to be cold, not to be thirsty. If you should have more than is necessary for these, you must, he said, use that surplus for good works. Up to now, the goods I have possessed have been sufficient for these good works. But I know, I said, that you have twice as much as I and that you are in possession of your rights and franchises in our city, so that I do not see what could be a cause of grief for you except insatiate desire and greed. Therefore, practice what $\mathbf{I}$ have said in my discourse; keep it in mind, study it, and consider whether I am telling the truth until you are just as convinced of this as you are that two times two are four.

\section{IX}

Let us examine carefully, I said, what kind of passion this insatiate desire and greed is. The insatiate desire for food will provide the beginning for our investigation. People give the name of greed to the act of being carried beyond what is needed in the matter of food, and they judge what is fitting by the need for nourishment. The need for nourishment is measured by the 
nurture of the body. If the food has been well digested, it will nurture the body; if taken in moderation, it will be digested. But we know that an abundance of food remains undigested. If this should once happen, the usefulness of the food is necessarily destroyed. But if the stomach should be distressed by the gnawing of undigested foods and excrete everything, the symptom is called diarrhoea, and the usefulness of the food is destroyed. For we do not take the food for the purpose of passing it through the bowels, but that it may be delivered to all parts of the body. But if food which has not been well digested should be distributed, it produces in the veins an unhealthy state of the humors.

Therefore, after you have learned what manner of thing insatiate desire is with respect to our bodies, go over to your soul and see there, too, the nature of insatiate desire; reflect on each thing which is matter for trouble, beginning with your possessions. Among these are some which it is not right to pursue zealously, such as pearls, onyx, and all the other [precious] stones which, as women think, bring beauty to those who have adorned themselves with them. To this class belong also garments which are interwoven with gold, or possess some superfluous elaboration, or require material imported from faraway lands, such as the silk that is called Chinese. Other possessions, such as those which contribute to one's bodily health, are fitting objects for one's zealous pursuit, and foremost among these are those by which we are fed, clothed, and shod. Nor should we exclude housing from among these goods. Things required by the sick also seem to belong to this class. Some things, such as olive oil, are beneficial both to the healthy and the sick, and of these goods 
some furnish a greater and others a smaller advantage to the bodies of men.

I think, therefore, that you have now clearly seen the standard for the extent to which we should possess these goods. Just as a cubit-long shoe is perfectly useless, so too it is superfluous and useless to have fifteen shoes rather than the two shoes we are using. Why are the two we already have not altogether sufficient for our use? It is enough to have two garments, two slaves, and two sets of household equipment. But not only, I said, do we have more than two garments but also our slaves and equipment and, in a word, all our possessions far exceed that number. For the profits we have from our possessions are many times larger than what is necessary for them to serve the good health of the body.

I see, I said, that some who have chosen the so-called life of pleasure spend not only twice and three times as much as we spend, but five, ten, and thirty times as much. In like manner, I see that you are maintaining yourself in the same way that I do; but unlike me, you are grieved-even though your wealth increases each year-when you spend perhaps one-tenth of your income from it, while nine-tenths are added to your resources. For I see that you do not have the courage to spend your wealth on noble pursuits nor on the purchase and preparation of books, nor on the training of scribes, both tachygraphers and calligraphers, just as you failed in the matter of training correct readers. Indeed, I never see you sharing anything the way you see me at all times sharing my own clothing with some of my slaves, and giving others what they need for nourishment and nursing; you even saw me paying off 
the debts of some people. I am spending all the wealth my father left to me, neither laying aside nor storing up any residue from it; although you are laying aside many times more than you spend, it is clear that you are often distressed. But still, you admit yourself that you never see me sorely grieved.

Can you not, therefore, perceive the cause for your grief, or do you wish me to tell you the name by which it is called? If you wish this to happen to you, be sure that there is a single cause for all griefs. The Greeks sometimes call it insatiate desire and at other times covetousness. They call it insatiate desire from the greediness with which one yearns, and covetousness because) the greedy always desire (to grasp a larger share) of what lies before them-so much so that, even if (they have) twice as much, they are eager to acquire (three times as much;) if they have three times as much, they desire four times as much.

Hence, they keep looking at those who have more than they and not at those who have less, and they seek to surpass those who surpass them and to have more than they do. If you will look in this way, I said, at all our fellow citizens, you will not find thirty who are wealthier than you. Hence, you are richer than all the rest of the citizens; in addition to these, it is obvious that you are richer than the slave population and the great number of women residents. If, then, our fellow citizens number about forty thousand and if you add to these the women and slaves, you will find that you are not satisfied with being richer than one hundred and twenty thousand, but that you also wish to surpass those thirty men who are richer than you; you are eager for yourself to be the very first in wealth-even 
though it is much better to be first in self-sufficiency and frugality, which is within your power. Yet preeminence in wealth is not a work of virtue but of fortune, which makes both slaves and freedmen richer than are we who bear the name of noble birth.

But even if, as you pray you may, you will possess more than all of your fellow citizens, you will not be satisfied; straightway you will be looking around for fear that someone in another city may be richer. Then, if you have fortune working for you to this end, you will go over to other nations and desire to become wealthier than the wealthiest among those peoples. Hence, you will not be richer than all men, but you will be poor because of your limitless desires. But if you were to measure what is fitting for you by the usefulness of your possessions, you would already have reckoned yourself among the wealthy or, at any rate, among the well-to-do. Be that as it may, $I$ count myself among them, even if I possess less than you. If you will win yourself over to this belief, you will no longer feel grief over the loss of anything; you will be happy insofar as you do not distress yourself over money.

If you will free yourself from this same greedy desire to be held in honor, you will be free from distress in this respect as well. But not only are you dissatisfied with the honor paid you by your close friends, but you wish everybody in the city to praise you. And yet, how very few of those who live in all Asia Minor know you at all? Perhaps, then, you will wish first to have them know you and, second, to have them honor you. But this desire to have everybody know you is a product 
of an insatiate love of glory, and the desire to be held in honor by all is the result of a foolish ambition. Hence, if you extend your desire to love of glory or ambition, you will have to distress yourself to a greater degree over those who do not know and honor youand they are many-just as you now lie awake at night over the possession of wealth. If, then, we will exercise ourselves constantly and vigorously in this direction, we will be free from grief. But how will we exercise ourselves, if we have not first been won over to the belief that insatiate desire is correctly called the most villainous passion of the soul? And so it is, for it provides a kind of foundation for covetousness, love of glory, ambition, lust for power, and love of strife.

First, therefore, you must keep ready at hand the doctrine on independence and self-sufficiency which is clearly connected with that on greed and insatiate desire; the man who hates insatiate desire and greed loves to be self-sufficient and independent. If, then, being free from grief lies in this alone and this lies in our power, we can now be entirely free from grief by keeping the doctrines on greed and independence ready at hand and by practicing each day particular deeds in the light of these doctrines. Some were able to do so from their earliest education; let us do so in order that this may be possible at some later date and in the way I just mentioned for those who were deprived of this early education. For who would not wish to be free from grief throughout his whole life? Or who would not choose this in preference to the wealth of Cinyras and Midas? 44

44. This lengthy discussion started above, p. 54. 
I went through these and many other points with my young friend and, at a later date, with many others. I won them all over immediately but I later saw that very few had benefitted from what I said. The passions have increased in the souls of the majority of men to such a point that they are incurable diseases. But if someone be still subject to passions of moderate strength and, in spite of this condition, be still able to have any understanding of what I said earlier, let that man set over himself, as I said before, some overseer and instructor, 45 who on every occasion will remind him, or rebuke him, or encourage and urge him on to cling to the better things by furnishing himself in all things as a good example of what he says and urges. If that man heeds his tutor's words, he will be able to build in himself a soul that is both free and noble. It would be a disgraceful thing to value highly the freedom which is so dear to man's sense of justice and humanity and still to disregard it in reality and nature and be a slave to such shameless and domineering mistresses ${ }^{46}$ as covetousness, meanness, love of reputation, lust for power, and ambition.

And yet, I would not hesitate to say that greed is the foundation of all these vices. What man who has greed in his soul can become good and noble? Who would not deserve to die a thousand deaths if he does not hate such a shameful thing as greed? The young who wish to be kept safe must much more hate and flee

45. See above, pp. 52, 36, 49.

46. See Xenophon, Oeconomicus, ed. E. C. Marchant (Oxford: Oxford University Press, 1904), i. 22. 
this shameful thing; if they have at first been brought up to an insatiate desire for money, they can no longer be helped after their fortieth year. Or, if you wish, make it the fiftieth year-so that no one may call us misanthropic or inhuman, as I was called by a man who was a slave to gluttony, lust, glory, and honors but who, because he was not wealthy, was distressed and said he was getting none of the things for which he longed.

In fact, when this man saw me joyful day in and day out for a considerable period of time while he felt unhappy himself, he asked me to teach him how to be free from grief. When I told him it would take many years to correct the passions which he had allowed to wax strong up to that time, he cried out and said, "Nothing is more misanthropic or inhuman than you!" He spoke as if $I$ could have hurried, if $I$ wished, to free him from his grief very quickly, but that I begrudged him this kindly service. And yet, no one can begrudge his neighbor this one lesson. It is profitable for us that all the men with whom we spend our time be free from the diseases of the soul and that neither love of glory nor any other passion of this sort has besmirched and dishonored their souls. The better these friends of ours will be, the more profitable will they become for us.

Coming back again to the one who truly wishes to become a man, I shall propose the common path to all things that will ennoble our souls. At the outset, a man must put over himself an overseer who, in each thing the man does, will remind him of what is being overlooked. For it is sometimes very difficult in one's deeds to distinguish between an act of stinginess and 
an act of thrift. And so, it is impossible for one who is just beginning to excise the disease of covetousness to make this distinction at this time. Just as in these men virtue borders on vice, so too, when the love of glory is excised, shamelessness springs up in base-born souls.

Young men who wish to be saved must have others to observe their errors, men who are old in years but who have given adequate proof throughout their whole lives that they possess the judgment of free men. When these overseers reprove them, the young men should neither resist nor be roused to hatred against them; they should be grateful and invite these guardians always to tell them the truth. When they have learned the truth, they must try to cut away something-even if it cannot be a large portion, at least some small part-from the bulk of their passions. They should do this, even if it should appear to be difficult in the beginning and to involve great hardship; consideration will show that the task will not be equally difficult as time goes on.

Later on, the complete subjection of the passions will be achieved more easily in proportion to the increase in strength of our reasoning power that is achieved by exercises which are calculated to weaken and diminish the passions. Where a reasoning power which has not been exercised has overcome even the greatest passions, it will clearly conquer them all the more readily when its excellence has been increased twofold in the course of time. For the power of reason itself will be much more excellent by virtue of the tests to which it has been submitted, and it will be struggling with passions which are becoming weaker. And either 
of these facts by itself is enough to make us hope for the future.

Consequently, in the very beginning of the program of exercises, it would not be right for a man to be disheartened because he sees that the progress he makes in curing his passions is slight. As time goes on, he will make great progress if only he will submit to hearing an account of his errors because he loves himself with a true love and because he desires to become a good and noble person-not merely to appear to be such. The recognition and cure of the soul's passions is accomplished according to the method I proposed. I shall now go on to speak about the soul's errors. 



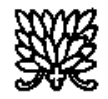

The Diagnosis and Cure of the Soul's Errors

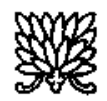





\section{The Diagnosis and Cure of the Soul's Errors}

The diagnosis and cure of the passions according to the method given have been discussed in the preceding commentary; now I will have to speak in the next place of errors. I begin now with what is the best beginning-as all agree, even if their actions do not demonstrate their agreement-by explaining what the term error means, in order that we may find no ambiguity in the following discourse, and by showing how all the Greeks are accustomed to use this term.1 They use it sometimes in the specific sense of things which have not been done according to right reason, so that error is an act of the soul's intellectual power alone; at other times, they use it in a more general sense so as to fit the irrational power. . . . 2

1. See Galen, De placitis Hippocratis et Platonis, p. 342, $11 \mathrm{ff}$.

2. There is a lacuna of about three lines in the text. 
[That both a false and reckless assent constitute) error all agree, but there is no agreement now about a weak assent. Some think that it is better to put the weak assent somewhere between virtue and vice. And they call it a weak assent when we have not yet persuaded ourselves of the truth of some judgment such as, for example, that we have five fingers on each hand, or that two times two is four. Perhaps, in the case of an old man who has spent his whole life in discovering truth, it would be an error to give a weak assent to something which can be scientifically demonstrated.

At any rate, the knowledge of the geometrician with respect to the things which have been proved by Euclid's elements has the same degree of certitude as does the knowledge of the majority of men that two plus two makes four. The geometrician has this same sure knowledge of the theorems on spheres (which are taught following the elements), as well as of all problems solved by these, and of conic sections, and of the theorems concerning sundials. If, then, he shall be somewhat doubtful and fail to have in these matters the strong assent which is called comprehension, one might agree that this is an error, because it is clearly the act of a geometrician. ${ }^{4}$ However, in the case of a man who has erred throughout his life, his mistaken judgments in matters concerning the knowledge, pos-

3. The words within brackets translate a conjecture by $\mathbf{H}$. Schoene which is adopted by De Boer.

4. See Sextus Empiricus, Adversus mathematicos, ed. H. Mutschmann (2 vols.; Leipzig: Teubner, 1912-14), II, vii. 151, p. 37; viii. 396, p. 193; Clement of Alexandria, Stromateis, ed. O. Stahlin (Leipzig: Teubner, 1905), viii. 5; Arnim, Stoicorum veterum fragmenta, II, Pp. 29f., 86 (fragments 90, 91, and 121). 
session, and avoidance of good and evil stand side by side with false assent or an assent that is reckless or weak. Hence, there is a danger in this matter that a small error 〈does) the greatest (harm) if we give a false assent in our judgment on good and evil. 5

According to the Academics and the followers of Pyrrho, who do not admit that we have a scientific demonstration of the things we investigate, every assent is of necessity a reckless one. But it is possible that this assent is also false; they say that the opposing opinions on good and evil which the philosophers propose cannot all be true, but it is possible that, perhaps, they are all false, so that the good is not pleasure, nor is it serenity, nor is it virtue, nor self-activity, nor any at all of the other things which the philosophers have enumerated. 6

First, then, the man who wishes to be free from error must consider whether demonstration of an obscure matter is possible; then, when he shall find this out, he must seek, not alone and cursorily, but for a long time and with the help of men who are most truthful, prudent by nature, and well practiced in intellectual speculations to discover what the method of demonstration is; then, when he shall be convinced that he has discovered it, he must thereafter exercise himself anew in it for a long time before he goes on in search of the most important things. This search

5. See Arnim, op. cit., III, p. 4I. According to the Stoics, rashness in assertion does affect the actual course of events as is pointed out by Diogenes Laertius, Lives of Eminent Philosophers, II, vii. 48 , p. 156.

6. See A. Goedeckemeyer, Geschichte des griechischen Skeptizismtes (Leipzig: Dieterich, 1905), pp. 40 f., 68, 224 f., 242, 246, 307 f., 816 ff. 
makes us happy or blessed-or whatever else one may wish to call it-after it has put us in possession of the good which is also called the end and fulfillment of life.

Are they not clearly reckless who attempt to discover things of the greatest importance without first convincing themselves that they understand scientific demonstration? I think they are quite reckless, since they are acting very much like those who make bold to declare some opinion about the theorems of practical and theoretical arithmetic before they have persuaded themselves to practice exercises with numbers. These men must of necessity fall into many blunders; in the same way, those who try to prove something before they have exercised themselves in the method of demonstrations cannot fail to fall into error. The large number of [philosophical] sects makes it clear that some charlatans are winning disciples; it is also clear that these charlatans would not have convinced anybody to accept their teachings as true unless they bore a certain similarity to the truth. Nor should we think that this similarity is a slight one. If the resemblance between the false and true were only slight, it would very easily have been detected over the long period of time during which both experts and ordinary people have examined it closely.

What Hippocrates said about the medical profession seems to apply to philosophy as well. Hippoctates said that similarities cause blunders and difficulties even for good physicians. Hence, if not only the ordinary physi- 
cian but even the very best fall into error because of similarity of symptoms, it is not unlikely that errors and difficulties occur even for good philosophers in matters relating to philosophy. Those who are well acquainted with twins readily distinguish between them even though they are much alike, while those who do not know the twins well cannot distinguish between them. So, too, those whom long and daily practice has not made experts in argument cannot distinguish between similarities in argument in the same way that the brothers of twins who live with them and know them well are able to distinguish one twin from the other.

As regards those who recklessly have made some pronouncement about what is good or bad in human life, their first and greatest error is the one which springs from self-love, or vain boasting, or conceit of wisdom, or ambition. For 〈we see〉 that some have misled themselves to believe that they are judging correctly; but others, for the sake of honor or for business reasons, have convinced their neighbors while they themselves remained suspicious of their own statements. Clearly, both groups are in error: the latter err with knowledge, and their evil would be one of passion; the first, however, would err through want of knowledge, and their fault would be properly called an error. ${ }^{7}$

7. The point here seems to be that want of knowledge leads to false opinion which is the source of error or "sin." He who has knowledge cannot err or "sin" in the specific sense of the term but only in a generic sense: his actions are bad, but they are not errors because they come from knowledge, even though the "correctness" of his judgment is due to self-deception. The man who suspects his own statement does not have knowledge but only an opinion which is a want of sure knowledge. This leads to false opinion which is the source of error or "sin" properly so called. So, too, later (see pp. 87-88), the first man 
Therefore, those men do well who have remembered Aesop's fable of the sacks ${ }^{8}$ and have turned their own opinions over to others for judgment, but certainly not to others who are such as they themselves happen to be, unpracticed both in the methods of demonstration and in other disciplines which sharpen the soul, such as geometry, arithmetic, computation, architecture, astronomy-some of them having had the instruction of neither a teacher of oratory nor of what is most easy to get, a teacher of grammar, but so unpracticed in words that they fail to grasp the things they hear me say. I have observed that this is the case; hence, whenever I say something, I ask them to repeat what I have said. As with the asses listening to the lyre, 9 the clear truth is that they have not actually understood what I said. Nevertheless, even these have come to such a point of daring and boldness that they are not ashamed when those who have learned their letters

makes a proper judgment but fails to execute it because of passion; the second man acts from the unsound and mistaken opinion that his own pleasure and serenity are true and proper ends and, hence, his failure to do good is an error or "sin" in the proper sense of the word. It should be noted that, according to Chrysippus (see Diogenes Laertius, op cit., II, vii. 111, p. 216) passions are, in a sense, judgments, since avarice, for example, is a [false] supposition that money is good. The deceptiveness of external things can lead to the perversion of a rational being (ibid., 89, p. 196). A man must rid himself of his passions because they are probably the reason why he falls into false opinion (see On the Diagnosis and Cure of the Soul's Passions, Pp. 31-32) and, thence, into error.

8. See Galen, On the Diagnosis and Cure of the Soul's Passions, p. 30 , and note 5 on page 28 .

9. An ass listening to the lyre is proverbial for one who can make nothing of music. See Menander, fragment 527 , in T. Kock, Comicorum Atticorum fragmenta; and Misoumenos, 18, in F. Allinson, Menander (New York: G. P. Putnam's Sons, 1980), p. 408, where it is translated "(like) a jackass at a musicale." 
mock them for being unable to recount what they have heard; they think that they know the truth and that those who have gone to school have spent their time to no purpose.

But I have not undertaken this discourse in the hope that I will help those people; most of them, even if they should be willing, will not be able to be helped, since they are no longer of an age suitable for instruction. But if a man is by nature intelligent and has previously been trained in learning the elements at least to the extent that he can repeat straightway whatever he may hear, or can at least write it down, he will benefit from this discourse-if he is really striving for the truth. For this much is entirely in his hands. However, he must first be inclined (to the truth) by nature and, next, he ought to have had a good education. If he is not naturally inclined to the truth and has been reared in villainous and licentious pursuits, he can never reach for the truth either by getting the impetus for this from himself or through the urging of another. Never did I promise that 1 would help such a man but, as I said, I shall try with all my strength to point out to any lover of truth the way which 1 have sought through my whole life and which I have convinced myself is the only way. This is the way of which I shall now speak.

\section{III}

For I think, I said, that those who have understood all that our ancestors have written about the method of demonstration should first test this method in other matters to see whether it really discovers any of the ob- 
jects it seeks; I think that the nature of such things can provide the evidence to those who have discovered them. Such is the case when one divides a given line into the designated parts. 10

Perhaps those who are altogether untutored understand nothing of what is said. I shall try to speak more clearly to them, as I would speak to asses. I understand by a given straight line a line traced on a perfectly horizontal plane; by designated parts, I understand those determined by the will of the one proposing the problem, whether he bids us to divide the straight line into five, or seven, or twenty, or one hundred equal parts. Either find your own method for making the division, or use a method taught to you by another. If, then, you divide the straight line into as many parts as you may wish, the fact itself will bear witness to you, and all the parts of the line divided in this way will be seen as perfectly equal; so, too, all (other) problems of this sort will be clearly and certainly discovered and solved by means of the ones which are clearly proved. For example, let us suppose we are instructed to draw a circle around a given square11 or, in the same way, to draw a square around or within a given circle ${ }^{12}$ and, again, to draw a circle around a given pentagon which has equal sides and equal angles.13 If anyone is able immediately to inscribe or circumscribe each of these figures by the method he

10. See Euclid, Elementa, ed. J. L. Heiberg and H. Menge (Leipzig: Teubner, 1839-1916), i. 10.

11. Ibid., iv. 9.

12. Ibid., iv. 6 and 7.

13. Ibid., iv. 11 . 
has learned, by doing this very thing he will give evidence that he has discovered the object of his search.

But the subject matter itself cannot give such evidence in such a question as whether the world did or did not begin to exist; nor can it tell whether the universe is finite or infinite, nor how great is the number of the ocean's waves. No question of this sort is decided by the very subject matter we seem to have here. However, if you are instructed 〈to draw) a polygon of twelve equal sides and angles (around or within a circle, you will do it immediately. And in fact, the polygon is clearly seen as inscribed or circumscribed just as the circle is seen as circumscribed or inscribed with respect to the polygon.

Hence, when we discover a method of demonstration which leads us to the object we are seeking and which gives clear evidence from the subject matter itself, we will have from this subject matter (no) small tests of the truth itself, and we may one day be so bold as to apply this method to questions which cannot give clear evidence of their truth. I do not ask anyone to make this venture immediately in the most important matters; if, however, the things which lead to happiness are the most important, I ask him to practice first in some subject matter which, on the one hand, refutes the man who falsely thinks he has found the things he sought and, on the other, gives confirmation to those who have truly found the objects of their search.

Such is the method we find in geometry, in theoretical and practical arithmetic, in astronomy, and architecture. Under the name of architecture, I include the diagrams and marking of instruments for telling time, both water clocks and hydrostatic clocks and mechani- 
cal devices among which are those called air clocks. All these things confirm the conclusions of those who discovered them, as is also the case in astronomy, where conclusions are judged, tested, and confirmed in the light of what is clearly proved-if, at least, eclipses of the sun and moon and whatever we see of the fixed stars and planets are to be included among the things which are clearly proved.

I see that these words are stinging the souls of all who, because of their advanced age, no longer have the opportunity of testing over a long period the demonstrative method in matters which are able to give it clear confirmation. For, as 1 said, ${ }^{14}$ because of self-love, or because of conceit of wisdom, or because of ambition, or concern for personal reputation, or vain boasting, or money-making, some convince themselves that they possess sure knowledge, and others even convince other men of this same thing. It is not strange if each teacher convinces his pupils by his own discourses, since some of these disciples are naturally dull, while others are keen-witted but untrained in the elements of learning. It suits braggart teachers to have such students since a disciple who is naturally intelligent and has had previous training in the elements will straightway look with scorn upon these charlatans, just as I looked with scom on many teachers, when I was still a lad, because they made bold to prove certain propositions which opposed those scientifically demonstrated in geometry, although they themselves had no idea of how to demonstrate them. If, then, by the method I mentioned, 15 vain boast-

14. See p. 77 above.

15. See p. 75 above. 
ing, self-love, ambition, concern for reputation, conceit of wisdom, and love of money are removed from the heart of the man who is going to search for truth, he will certainly arrive at it. After he has practiced himself in the truth, not for months, but for years, he will sometime thereafter inquire into the doctrines which can lead to happiness or misery. On the one hand, 1 hesitate (to encourage) to so long a course anyone who still feels the sting of any of the passions I mentioned. But, on the other, I hate those teachers who plot some treachery and slander (against us). For they are accustomed to win their own disciples over to these vices beforehand so that they never submit to offer their ears to such arguments as I have employed up to this point.

It is very easy for a teacher who speaks with a dignified mien to persuade uneducated lads that the easiest way to wisdom is the way which is common with all the Cynics. In fact, they say that their way of life is a short cut to virtue.16 But some of them correct this notion and affirm that the Cynic philosophy is not a road leading to virtue but a road leading through virtue to happiness. Still others, giving the truest description, say that it is a short road to vain boasting through the unskilled rashness of men such as they. Just as all the Cynics admit-at least those whom I have seen in my lifetime-so also some self-styled philosophers do not deny that they shun the exercise of rational speculation.

Then, after they have left us, they deem it beneath their dignity to hold converse with the men they meetthe herders of goats and cattle, the diggers, the har-

16. See Diogenes Laertius, Lives of Eminent Philosophers, II, vii. 121, p. 226. 
vesters-because, as they say, these men are untrained in speech and do not follow their arguments. They say this as if they themselves had at one time received a basic education and had not all of a sudden heard from some teacher what he considered to be demonstrative discourses on the end of life, 〈on happiness, and on misery, which they, because of their lack of training, had believed. For if, as I said,17 the similarity of false arguments to true is the reason for false doctrines, and if it takes an expert in each subject matter to diagnose them exactly, the man who has suddenly become involved in a debate cannot possibly distinguish and separate the false arguments from the true.

We have a positive proof of this in the so-called sophisms, 18 which are false arguments which have been cunningly changed so as to bear a similarity to arguments which are true. The falsity of these is clearly evident because the conclusion is not true. Since, at any rate, the arguments are false, they either have something false in the premises or the conclusion is badly drawn; these defects, however, are not readily seen in the sophisms; and on this account, it is diffcult for those unskilled in argument to detect them.

Furthermore, where there is agreement that the argument is false because the falsity of its conclusion is evident to all, but where, nonetheless, the solution of the sophism escapes the unskilled, the safe thing would be for them to suspect all arguments. They should give assent to no argument until they can definitely persuade themselves that they have the

17. See p. 76 above.

18. See Arnim, Stoicorum veterum fragmenta, II, p. 90 (fragment 272); De placitis Hippocratis et Platonis, p. 801, lff. 
ability to grasp the similarity which the false arguments bear to those which are true. They will convince themselves that they do possess this intellectual competence by permitting whoever wishes to do so to put it to the test by proposing sophisms to them.

What other advice is given by those who see fit to exercise their students in the solution of sophisms? Their advice is exactly the same. Since, as I said, the solution lies in showing the similarity of the false argument to the true, one must first have understood the nature of arguments which are true. For if a man has become so experienced in true arguments that he accurately and quickly recognizes their nature, he would still have no difficulty in recognizing those which are false. I proved this when I took lads who had previous experience in learning and taught them to recognize true arguments. If any of those present wished to do so, I asked them to propose sophisms to these young men; immediately the students recognized the absurdity of the sophisms, either from a fault in the form of the syllogism or because something in the premises was false. And so it became clearly evident to these old men, who were wise in their own conceit but unable to solve the sophisms, that their ignorance of true arguments had brought them to this experience.

Do they not, then, deserve our utmost condemna. tion because their reckless assent has brought them to a miserable life? Everyone agrees that a false opinion regarding the end of life leads to a miserable life. Some people are so inexperienced in distinguishing true from false arguments that at times they feel sure of the truth of an opinion but fail to see that what they have stated is a contingent argument-just as if what- 
ever opinion they hold is clearly proved. But they bid us to follow and believe without proof, and often, when only an exposition is required, they try to confirm it by a proof. Others have not learned the difference between proof and an argument which is primarily and of itself sure and evident; nevertheless, they undertake to explicate these matters even when they have not given them careful consideration or reflection. And this has happened to many who have had long experience in philosophy.

Why, then, in heaven's name, do you think that the ignorance and pretense of wisdom of people such as these can easily be cured? If a man has a tumor which has hardened over a period of three or four years, his induration is indissoluble. Who can cure the induration of thirty or forty years' standing which grips the souls of such old men? Suppose, if you wish, that cure is possible; consider, then, whether the cure of such a tumor will require days or months or years. Therefore, do not wonder that I do not deem it altogether worth my while to carry on discussions with many of those who boast that they are philosophers. I know that these boasters are inferior to any man who is by nature prudent and who has been given that education which the Greeks have held in high regard from the first. Men with this education . . . and readily recognize-and what a man readily recognizes, he distinctly follows. ${ }^{19}$ But I have often had experience with those philosophers who quarrel with and pretend not to understand any position which is at variance with their own. At any rate, I have discussed with many

19. The text is hopelessly defective at this point. 
philosophers on many occasions the question of what ways of life are in accordance with any given end. Although the very philosophers who possessed a keen understanding by reason of their early instruction all described the various kinds of life which are in accordance /with any given end), they recognized the strength of my position (and adopted it).20 But, as I said, those philosophers who have grown old and are wise in their own conceit were the only ones who contradicted my position; when those who were present laughed them to scorn, they turned on their taunters and heaped abuse upon them.

I have often, together with many men, made an investigation into the ways of life which are in accordance with any given end, and you have these investigations set forth in other commentaries of mine.21 There $I$ have clearly set forth many examples of the errors into which these philosophers fall. A false judgment underlies all the deeds and words wherewith the adherents of the different sects oppose and contradict each other; that those words and deeds which are mistakes common to every sect are all really bad and are errors is certainly clear once the true sect has discovered not only the end but also the way of life which is in accordance with that end. Here you can also learn just how passion differs from error.22 Suppose it were to happen that a man laid down the principle of

20. The text is defective. The first set of bracketed words represents a conjecture by $H$. Schoene; the second, by $H$. Diels.

21. See Galen, XIX, p. $46,3$.

22. Galen makes the distinction between passion and error again in the fourth book of De placitis Hippocratis et Platonis, P. 342, $11 \mathrm{ff}$. See On the Diagnosis and Cure of the Soul's Passions, p. 28 above. 
doing good to men because doing good to people is a true end. If he then neglects to do good either because of sleep, or laziness, or love of pleasure, or some such reason, he has erred because of passion. But if someone has decided to provide only himself with pleasure or serenity, and on this account refrains from helping his fellow citizens or members of his household when they are being treated unjustly, this man has erred because of his unsound and mistaken judgment and not because of passion. 23

\section{IV}

A false notion regarding the end [of one's conduct of life] is, then, the beginning of many errors. One after another, errors spring up from it as from a root. But it is possible for a man who has not been deceived in his opinion about the end to err in some particular because he did not understand what was consistent with the end.24 Furthermore, as I said above, I have gathered together for you in other commentaries the actions which are consistent with each end. But now let me speak only of the chief errors; I think it is better to take these up again inasmuch as a general view of the subject matter is easy to remember. Since the source of human happiness lies in the consideration of the end, all men who esteem themselves have naturally turned to this investigation. But they were all hasty in their declarations-or all were except one, and he may have expressed his opinion without judging

23. See above, p. 77 and note 7 .

24. See Arnim, Stoicorum veterum fragmenta, III, p. 9 (fragment 28). 
whether the demonstrations [offered] are really demonstrations or only seem so to those [other] men.25 Hence, the man who observes and is watchful over his errors must first understand this: after he has listened carefully and accurately to men who think that they have demonstrated the objects of their investigations, he is altogether justified in then trying to put these demonstrations to the test.

Again in this matter, after he has heard what criteria these men lay down for truth in their arguments, he is again perfectly justified in trying to examine these criteria to see what sort they must be. Let him take counsel with himself and keep watch so that they do not bring in a second criterion which requires a further criterion which then needs another one for that. Let him join together with the men who seem to him to be most truthful, and with them let him be very careful for a long time to suspect the escape ad infinitum.26 In this same way and with these same men, let him consider which criterion is the primary criterion, (the criterion which is self-evident and which must recall the rest of the demonstration to anyone who has gotten even a confused gxasp of this norm. All men would agree that this norm, without question or dispute, can give evidence of this same power in every demonstration. $)^{27}$

Henceforth, the man who looks to this criterion must

25. On the Stoics' opinion that a perfectly wise man can hardly be found, see E. Zeller, Die Philosophie der Griechen, III, Part 1, Pp. 253 n. 1, 276 n. 1.

26. See Sextus Empiricus, Adversus mathematicos, vii. 440. (Arnim, Stoicorum veterum fragmenta, II, p. 86, fragment 118).

27. The Greek text for these two sentences is very defective. The translation represents a reconstruction by $\mathrm{H}$. Diels. 
bring all things back to it one after another-a process which some philosophers 28 called "analysis" because it was a way back through the intervening stages to the primary criterion. This task is difficult enough, as you learned many times indeed in the cases of those who were wise in their own conceit, the shameless ones who were laughed to scom because they could not reduce a given problem to the primary criterion. The man who wishes to become scientific must attend studiously to himself; he must, as I said before, exercise himself successively in many things which can give evidence of themselves to those who discover them.29 Such are the things we find in the sciences of numbers and lines on which astronomy and architecture are based.

\section{$\mathrm{V}$}

Let me give an example from building to make this clear. When a city is being built, let us assume that the problem is set before those who will dwell in it that they resolve not to guess but to learn accurately each day how much of the day's time has gone and how much remains before sunset. This problem, according to the analytic method, must be reduced to the primary criterion if anyone should be going to discover the solution to this problem in the manner we learned in the study of sundials. And, again, the analytic process must be reversed to one of synthesis when, in the next place, the problem travels the same road but

28. Aristotle and his followers.

29. See above, p. 82. 
in the opposite direction. This process of synthesis we also learned in the same study of sundials.

After we have discovered in this way an integral and common method and after we have learned that we must use lines to make such a measure for the parts of the time of day, we should then pass over to the bodies which are going to receive the marked lines and pointer of the sundial; and first, we must investigate of what shapes the bodies should be to be suitable for the line-markings we have discovered. Next, we must find in each of these [bodies] from analysis and synthesis what sort of marking this should be. Whenever the method of logic gives us clear assurance that we have found the subject matter, then we must turn to the actual performance of what this method has discovered for us and examine how we will produce a level surface for the body which is going to be inscribed with lines.

After analysis and synthesis have discovered this for us and after we have then made ready a body of the proper sort, we must seek for the instruments with which to inscribe the body. After analysis and synthesis have discovered for us the instruments, we must try to prepare bodies possessing the form which the method has indicated. When we have inscribed the line-markings successively on many figures, we must turn them over to men for actual trial to see if what the problem proposed has been accomplished. For when the first line receives the $\langle$ first $\rangle$ ray of the sun and, in the same way, when the last line receives the last ray, and this is clear in the case of all the inscribed sundials, we will now have one clear token that what has been proposed has been accomplished. Again, we 
shall have a second criterion when all the inscribed surfaces are in agreement with each other; we shall have a third when a flow of water shows that they are equal. For our reason discovers that this will serve as a criterion for the truth of the dials which we have inscribed with lines.

This is what I mean. Pierce a vessel of whatever material you wish and put it in clear water as soon as you have seen the first ray of sunlight. Next, when the inscribed dial tells you that the first hour has passed, mark off whatever part of the vessel has been filled with the water. Next, after you have immediately emptied it, put it again into the same water. When the sundial tells you that the second hour has passed, examine the vessel; when you then find that the water in it has come to the same point as you marked for the first hour, again empty it quickly and put the vessel right back into the water and again examine whether, at the third hour, the dial shows that the water comes to the same point in the vessel to which it came at the first and second hours. When you find that this is so, empty it again and replace the vesse! in the water until the fourth hour; when you again see that the water has come to the same point in the vessel, again empty it and replace it in the water in the same way; then examine it at the fifth hour. When you discover that at this hour, too, the water has come to the same spot, and also at the sixth and thenceforward hourly until the twelfth, unless you are completely ignorant, you will be convinced that the sundial has been properly marked with lines since the problem has been demonstrated.

And the problem was that the whole day's time is 
divided into twelve equal portions. Men chose this number because it is a most useful one; it has halves, thirds, quarters, sixths, and twelfths-parts which no number before twelve has nor any after it until you come to twenty-four. They rejected twenty-four because it was too large; because they judged that the number twelve was just right, they divided the whole day's time into twelve parts. Because they have proved by experience that a division into twelve parts is a useful one, both the Romans and many other people use it, apportioning their whole estate into twelve parts when they make wills and dividing into twelve portions most of the measures and standards we use in the course of life. If you tell me to do so, I shall sketch out a sundial by this method, whether you wish to divide the whole day into twelve parts or into some larger number; you will find in the latter case that what I proposed has again come about, and you will realize it from the fact that the measurement of the pierced vessels agrees, from the fact that all the inscribed lines are in agreement with each other and, in addition, from the fact that the first and last lines on the dials mark out the beginning and end of the day.

In this way reason has also sought by the analytic method and discovered how to mark out the water clock, ${ }^{30}$ and the test for this method is clear even for

30. A cylindrical container was generally used for the ancient water clock. On the exterior surface of the container, four vertical lines would be traced to correspond to the solstices and the equinoxes. Using a sundial as a guide, the twelve hourly stages of the water would be marked on each vertical line appropriate to the season. H. Sauppe, in Philologus (1886), XXIII, 448-54, elucidates the process with special reference to the text of Galen. He tells us to conceive of a glass container into which water is flowing at a uniform rate. On the outside surface, twelve horizontal lines 
laymen. For the uppermost line, which marks the twelfth hour of the day, is highest where the clock measures the longest day, and lowest where it measures the shortest day. In the middle is the line measuring the equinoctial days; the space in between the seg. ments of the edge of the water clock points out to you the days which come after the four days we have mentioned. Starting from these segments, you. will find that the segment next to that which indicates the longest day points out how high on the highest line the water will rise 〈on the next day), after the twelfth hour has been completed. After those two, the third segment from the turn will point out /the third) day, and the next, the fourth. By proceeding in the same way, you will find that the one line on the water clock which I called the highest measures all the days of the year. Moreover, you will also find that the other lines which are lower than the highest line measure the other hours, on all days of the year the first line after the twelfth signifying the eleventh hour in its different parts, as I said above in the case of the longest line, and the

are drawn in such a way that they show the number of hours of the day which have passed in proportion as the water rises to any one of the lines. These twelve lines cannot run in a straight line because they must have different heights according to the different seasons of the year. "For the uppermost line (which marks the twelfth hour of the day) is highest where the clock measures the longest day, and lowest where it measures the shortest day." These horizontal lines are, therefore, divided into four parts by four perpendicular segments, of which the first corresponds to the time of the summer solstice, the second to the autumnal equinox, the third to the winter solstice, and the fourth to the spring equinox. The spaces between the perpendicular lines are marked on the edge of the container. This was an advance over the sundial because it made it possible for people to determine the hours even on cloudy days. 
next after that indicating in like manner the (tenth) hour in all its parts, and the next again indicating the ninth hour, and the eighth, and the others, down to the shortest line which finds the first hour, just as we saw in the case of the sundials. And after the water has been filled up in the clock, just as the first and the other [lines] up to the twelfth seem equal to one another on any given day, so they appear unequal to those which go before and come after.

Did you not, then, desire to discover such a method, whatever it is? Did you not perceive your own pretense of wisdom? Ignorant as you are of these problems, would you find a solution in a whole year or, to speak more accurately, in a whole lifetime? No one man discovered these in his lifetime. First, the elementary theorems were investigated and discovered; then came men of a later day who added to these theorems that most marvelous reasoning which, as I said, is called analytic; 31 thereafter, both these men and others who were willing to learn exercised themselves in this analytic reasoning to the greatest extent. Thus, little by little, the theory of geometry progressed, although the geometricians can point to no such handiwork as I have narrated in the case of sundials and water clocks.

But the men who made such investigations were neither rash nor were they charlatans as are those who profess either to be seeking wisdom or to have found it. These men brought to themselves the truest honor; they were eager to exercise the noblest power in their soul and to bring that power to its perfection. Ob-

31. See above, p. 90 and p. 93 . 
viously, I mean the power of reason. When this becomes vigorous through exercise, these men enjoy themselves more than those who are slaves to bodily pleasures. Surely, it is because of no other power that we differ from goats or dogs or swine or sheep or asses; no other contemplation brings greater delight to the soul of a man of good natural disposition than does the process of analytic reasoning, at least whenever a man is making progress in it. For it is a laborious task in the beginning, as is the case with practically all other speculations. However, even if it were to bring no cheer to the heart, the very prospect of applying it to the most important problems would make it a good thing to practice because, as I said, ${ }^{32}$ it has the special characteristic of providing immediate evidence, and this is not possible in the things which philosophy discovers.

This is why it is possible for those who utter rash nonsense in philosophy to be shameless. Those who have marked a sundial or water clock incorrectly stand clearly convicted of their error by the very fact, but the refutation is not so clear in philosophical speculations. In philosophy a man can say whatever he wishes whenever, without shame and without a reasonable method, he contends that he is being instructed by the very subjects on which he is speculating. If these subjects have taken voice and speak to those philosophers alone, their pretensions are reasonable; since the subject matter is always silent and speaks neither to the philosophers nor to us, clearly only the reason within us will discover the nature of the subject

32. See above, p. 81 and p. 91 . 
matter under investigation. Therefore, let the man who can first discover this nature demonstrate it in matters which give clear evidence to him; let him give us a method to which every problem of analysis is subject; after he has sifted out the arguments which look the same and has separated the true from the false, let him show where it is possible to detect the evil. If he should fail to do so, he would no longer be worthy of credence in matters which are not evident.

All men agree to the truth of this except those who are rash in the conceit of their own wisdom. For them the path to the truth is not long and uphill, as Hesiod $^{33}$ described the path to virtue, but is a shortcut or, rather, simply no road at all. For if the very subjects to be investigated reveal their own natures to all men, there is no need for those who exercise themselves in the methods of reasoning to waste their time.

Would you men who are so very wise in your own judgment not also agree that it is clear to the rest of us who are not wise with your wisdom that all men must know the truth of all things since the nature of these things can reveal itself? They back down again when this question is put to them and they say that the subject matter does not instruct all men in this way. When we again ask them who are the ones who are thus instructed, they reply that they and only they enjoy this instruction. What else can they say and still protect the false pretension which they at first deliberately chose?

But we certainly do not believe these men who prove whatever they wish to prove. For why, in heaven's

38. See Hesiod, Works and Days, ed. A. Rzach (Leipzig: Teubner, 1918), lines $290 \mathrm{f}$. 
name, do the subjects under consideration reveal their natures to these men alone? Surely, it is not true that they alone learned nothing from their elementary training. This is false because many men have failed to learn their elements. Is it true that they exercised the rational power of their soul in mental training which in itself could, in fact, provide evidence for themp ${ }^{34}$ Indeed, they never undertook this sort of speculation. Perhaps they maintain that only they are born intelligent and see things by direct apprehension, as Lynceus $^{35}$ saw things beneath the earth. If, then, the soul of these philosophers enjoys such sharp vision of these things, why is it that they are the most ridiculous of all men in those matters wherein the very discovery provides evidence to the genuine discoverer? For no one of them could ever discover a problem of this sort. Although other men understand when investigators discuss and explain the problem, these philosophers alone (fail to understand it) because of their intellectual sloth and mental dullness. Even if they pay close attention (and any of them might happen to do so), they still cannot even repeat what has been said.

What blindness in recognizing one's own errors is greater than this blindness of theirs? They see that they are duller than ordinary people when it comes to understanding and remembering the facts of arithmetic, geometry, architecture, and astronomy, but they think

34. See above, pp. 95-96.

35. Lynceus, one of the Argonauts, "excelled in sharpest vision; if the report is reliable, that hero saw easily and distinctly even what lay beneath the earth"-Apollonius of Rhodes, Argonautica, ed. R. C. Seaton (Oxford: Oxford University Press, 1929), i. 153-55; see also ibid., iv. 1466, 1478. Apparenty, a confusion of this hero's name with that of the animal gave rise to our expression "lynx-eyed." 
that they have discovered the truths of philosophy with such ease that they make bold to show forth and explain these matters apart from demonstration and logical method. That they choose to flatter themselves and that they are not seeking the truth we can recognize from the fact that they argue. individually against an opinion only among their own followers, but accuse all others of being in error. If $I$ should gather them all into the same place, they refuse to stand their ground; they offer a man's modesty as their excuse and say that they cannot speak when a crowd is present. They maintain this even though they are not too modest to speak every day when they have twenty, thirty, or more listeners. But if I shall ask three or four Platonists to be present at the gathering, and three or four Epicureans, and an equal number of Stoics and Peripatetics, or three or four Academics or Skeptics in addition to these, so that there are altogether twenty philosophers, and, over and above these, twenty others who have exercised their intellectual power in mental training but who have no knowledge of philosophical discourse, in this case all of these men refuse to submit themselves to such a gathering.

Sometimes, however, forced by men who belong to no sect but who are practiced in speaking, they might agree to encounter a gathering of these men. While they are wrangling and keep bringing up the same arguments, it often happens that a geometrician has come among them, or some physicians, or other men who are fond of argument and have been trained in the disciplines, who neither practice their profession any longer because they are wealthy nor have made 
themselves subject to any philosophical sect. In my usual manner, I asked them to pass judgment on the arguments then being presented; one of them said that the controversy would be settled very nicely if we would go into the void which, according to these philosophers, encompasses the universe and would see whether it is the nature of any body placed in it to remain in one place or to move to some other place.36 This reply pleased all the others; only the philosophers refused to stop their obstinate arguing with the others and with me because they could not see the difference between probable arguments and those which are certain and necessary. When neither side has a certain and necessary demonstration, it remains possible that a body does or does not stay in one place in a void. ${ }^{37}$

\section{VI}

Although I have slight hope of putting a stop to their pretense of wisdom, it seemed opportune to me to say something so as not to let this pretense go before it had been put to the test. This I consider of no slight importance. So then, I said, let us agree that every demonstration begins from things which are most evident. However, neither the Academics nor the Skeptics admit the first transition from these evident things to what is not immediately evident, although the rest of us are agreed with one another on this. But in overcoming their difficulty, we discover something else.

Since some objects are evident to the intellect and

36. See Arnim, Stoicorum veterum fragmenta, II, PP. $174 \mathrm{f}$. (Fragments 552, 553, 554, 555). The one replying seems to have been a master builder or architect. See pp. 104-5.

37. See Arnim, loc. cit. 
others to the senses, these objects sometimes seem to be at variance with each other. To begin with, this very question needs a trained man to show that these two objects are not at variance with each other. Next, it is very important to distinguish these evident objects from those objects which are not clearly evident. For some men fall into error because, in their rashness, they give their assent to objects as clearly evident which are not yet clearly evident. And why do you wonder, I said, if this happens to rash men in matters which are clear to the intellect, when each day you see that there are some who suffer this same experience in matters which are clear to the senses? Certainly, when men have seen someone coming from a distance, they say that the man approaching is Dion, for example, just as if they had seen him distinctly. The result is that sometimes, when the man who was approaching was seen from close at hand, it was clear that it was actually Theon and not Dion. If, then, the appearance of things seen from afar and close at hand is indistinguishable, those who disagree with each other about things which are seen from a distance will never refute each other nor be refuted. But if the clarity of things seen from close by is different from the clarity with which we see things from afar, (those who have no experience of the clarity which comes from things close at hand $)^{38}$ are likely to be wrong.

Therefore, you must first bear this in mind before you pass over to objects which are clear to the intelligence and see whether you have ever spoken rashly.

98. The text is corrupt; the bracketed words represent a conjecture by $\mathbf{H}$. Diels. 
Look at this man who is coming toward you-Menippus, for example-who came closer and was recogmized as Theodore. Or did you, your whole life through, refrain from such assent as men call a hasty and rash judgment? I am speaking to you, and to you alone. No man can show that I ever blundered in this way; from my youth, I was in the habit of holding myself aloof from rash assent both in matters which appear clear to the senses and in those which appear clear to the intellect. When I came to the discussion of these topics, I urged you to remember; and now I urge you again to keep it in mind so that you do not give a false assent to anything. Each day I see many of my friends giving such false assent. When men are making all sorts of statements, some of them refuse to believe when one man speaks; but when three or four affirm the same thing, they do not hold out against them. Others give their assent even to one man, but they rush in headlong haste to give their assent to two, or three, or four, before they determine whether it is possible that all these are telling the truth for one common reason or are all lying for one common reason. It is better, then, to go slowly in this case, as I do, even if those who give hasty assent ridicule me and call me the most incredulous of men. Indeed, as soon as some of my friends learned from somebody that some person from abroad had arrived, they announced his arrival to me, but were proved liars. Whenever I reprove them for failing to make themselves less prone to error for the future, they are angry with me and say that they are not personally to blame for the false report. They believed this man who told them, and the error is his alone. 
They say this because they do not wish to be accused of consenting to every rash assent.

I make a practice of saying that this man told me something about somebody; if they, too, were to speak in the same way, they would not be victims of an error. But now, because they have fallen into error by believing the man who told them, they proved not only that he was mistaken but that they were mistaken with him, even though, in declaring the matter, they could have said, not that this friend of theirs from abroad had arrived, but that they heard of his arrival from someone. Since, then, they continue to give hasty assent in matters which subsequently prove that they were mistaken, what must we think will happen to them in matters which are not evident and rather difficult to grasp? It is easier to keep one thing always in mind than to stand one's ground (before every ob. ject which manifests itself $\rangle^{39}$ with clarity and exactness, but it is very difficult because most people are unwilling to do this.

When I sought the reason for their rashness, if it was not greed, it was (the pretense of wisdom $>$ which revealed itself as the cause of such errors. For when they see that people praise those who are quick to discover something either by the senses or the intellect, they think that they will prove themselves better than their neighbors by the speed of their knowledge; what they display, however, is the speed of their ignorance (and not of their knowledge). This, I said, is what I had to say in general to all those who are rash in their speech.

39. The text appears to be corrupt; the bracketed words represent a conjecture by $H$. Schoene. 


\section{VII}

Let us return to those philosophers who make rash assertions about bodies which stand or fall in a void.40 This master builder would not have declared his opinion before he had gone into the void of the universe and put the matter to the test of experience and had seen clearly whether each of the bodies in the void stays in the same place or changes its position. I know that he uses for his demonstrations principles which are clear and to which all agree without dispute. But you, the philosophers, have no clear knowledge of these things, yet you rashly affirm that they can be understood with the greatest clarity, as I heard quite recently when two philosophers were involved in a dispute. One of them thought that water was more dense than wood, while the other held that wood was more dense than water; each of them looked up and down and proposed lengthy arguments. One of the philosophers had as the chief point of his argument that a compressed substance is more dense and, therefore, wood is more dense than water; the other argued that the water contains less void [and, hence, is more dense]. They kept talking like this for a long time, offering the assurances of arguments which go so far but do not demonstrate the point, as if it were impossible to come to an understanding of the matter by sense-perception which, as you know, is what we do.

The philosophers still wanted to discuss the matter and asked the master builder by what method they might recognize the greater density. They said this could not be done by the beam of the scale nor by

40. See above, p. 100 . 
means of a vessel filled with water. For we can weigh the wood, but surely we cannot fill the vessel with the wood, although we can fill it with water. While they kept up this usual line of talk of theirs, the master builder laughed and said, "All of you who are wise in your own conceit are always like this. You think you know about things which are beyond this universe-things about which we can conjecture but which we cannot grasp with scientific knowledge. Yet, you fail completely to understand things which are sometimes grasped even by the ordinary, everyday man, such as this very problem which is now being proposed, namely, to compare the weight of wood and water."

Everybody asked the master builder to compare with scientific exactness the density of wood and water; he explained it quickly and clearly so that everybody present understood-except the philosophers alone. He was forced to repeat the same explanation a second and a third time for them, and still they scarcely understood. And so the master builder said that it was reasonable for many men to say that these philosophers have nothing but a pretense of wisdom. "Those who are senseless," he continued, "are refuted by the things which can be known by all; those who are wise in their own conceit are refuted by the things which cannot be known."

I took up his argument and said that this happened with good reason to men who never submitted to training themselves in how the transition must be made from what is clearly known to things which are not evident, and who never had the patience to learn about things which can give evidence to those who dis- 
cover them but can refute those who fail to make this discovery. "But so that you may laugh and understand how great their conceit is," I said, "I wish to tell you one or two of the doctrines which these men rashly profess as they arch their eyebrows. Let me tell you this first, especially since a philosopher has comeone of those Peripatetics who believe that there is only this one world and that there is no void either beyond it nor within it." 41

Pointing to a Stoic and an Epicurean, I went on to say, "Each of these differs from the Peripatetics in two ways. The Stoic says that there is no void in the world, but that there is empty space outside it. ${ }^{42}$ The Epicurean grants both these principles, but differs from the others in another respect. ${ }^{43} \mathrm{He}$ does not admit that there is only one world, as does the Stoic, who in this respect agrees perfectly with the Peripatetics. But just as he maintains that the void is infinite in size, so also does he say that there are in it an infinite number of worlds. I listened to what the three said in their desire to advocate their own dreams, but it is quite clear to me that they have no demonstrative argument, but only probable. and likely arguments-and sometimes not even these. You will know that I am not lying if you urge each of them to give some demonstration for the very problem under consideration." And so they affirmed what we already knew from the books which they had written. But all those present saw clearly that none of them offered a compelling argument or

41. See H. Diels, Doxographi graeci (Berlin: G. Reimeri, 1879), p. $817 \mathrm{a}, 11$; p. $327 \mathrm{~b}, 8$; p. 338a, 20.

42. See Arnim, Stoicorum veterum fragmenta, II, Pp. $170 \mathrm{ff}$.

48. See H. Usener, Epicurea (Leipzig: Teubner, 1887) , p. 213. 
one akin to geometric demonstartion but that their argument was compounded of dialectical proofs such as the orators use.

We have been talking about the [wise men who alone are] rich.44 Let us turn now to ourselves who are not rich; let us again ask some [truly] wise man 45 whether it is right for these philosophers to proclaim that they themselves are the only ones who know the truth, since they are held in low esteem by all, laymen and philosophers alike. For it is very strange, I said, that no one commends any of these wise men except the members of their own flock. Who, then, is more likely to know the truth? Is it the man who submits to the judgment of all true philosophers and also to the decision of those trained in all the other skills which depend on reason, those skilled in numbers and calculations-the geometricians, the astronomers, the architects, the lawyers, the orators, the grammarians, and the musicians? $O r$ is it he who declares himself winner by his own judgment, who would carry not a single vote if he should allow other judges to put him to the test?

For the present, let this be the sum total of my remarks on errors.

44. The words within parentheses have been supplied by the translator to make clear the irony of "wise." According to the Stoic paradox, only the wise man is rich.

45. See above, p. 100 . 



$$
\text { 移 }
$$

Interpretation

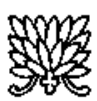



Interpretation

The passions have always held a key position in man's age-old and untiring efforts to design a consistent conduct of life. Their nature, their origin, their blessings and their danger, their unbroken power, and their mastery have been the mother soil on which human tragedy and comedy, disease and crime, man's greatness and disgrace have always drawn heavily.

In the last centuries, the passions underwent a significant shift in the classifications of human knowledge. While they are treated today (under the guise of emotions) in those divisions of natural sciences which emerged in the nineteenth century as psychology and psychopathology, they once belonged to moral philosophy under which they were listed in the great French encyclopedia of Diderot and d'Alembert. With the rise and growth of Cartesian thought, the ancient 
antagonism between the ruling power of reason and the opposing force of the passions began to usurp the major area in many of modern man's moral systems, though reshaped and reformulated in the scientific vocabulary of the time. The Platonic ancestry of this antagonism is easily forgotten; and the two souls, which were believed by Plato to be at the root of the antagonism, have no more than historical interest.

Galen's treatise on the passions can be called a treatise on ethics from which Galen emerges almost as a modern; indeed, it is the mastery of the passions through reason which appears as the basic theme of the treatise and the ultimate goal of his treatment of the passions. Conscious verbalization, which is unquestionably the main carrier of the more systematic and coherent psychotherapeutical devices of our time, is the continuous thread which appears, then fades, but always reappears throughout Galen's treatise.

It seems that Sprengel, 1 in a few pages of his correspondence on Galen's philosophical system, was the first modern author to discuss Galen's views on the passions. On one occasion, he cites Galen's De animi peccatorum notitia as one of the sources from which he derived his conclusions. Sprengel represented Galen as an eclectic figure who in his moral philosophy acknowledged his debt to Plato, Aristotle, and the Stoics. The reader of Sprengel's eleventh letter is left with the impression that Galen, though antagonistic to views held by the Stoics in certain theoretical matters, still adopted the Stoic method of treating the passions.

I. K. Sprengel, Vorträge zur Geschichte der Medizin (herausgegeben von Kurt Sprengel, 1. Band, 1. Stück, Halle in der Rengerschen Buchhandlung, 1794-96). 
The next author who discussed, though briefly, Galen's moral thought was another nineteenth-century medical historian, and also a very eminent one, Charles Daremberg.2 Again Platonic and Aristotelian sources of Galen's moral thought were stressed. Daremberg did not cite the crucial passage in Sprengel's correspondence, nor did he list Stoic sources of Galen's moral thought. But he listed among his source material Galen's De animi affectuum dignotione et curatione. ${ }^{3}$

We now turn to those authors, very small in number indeed, whose thorough knowledge of our treatise cannot be questioned and whose comments deserve greatest attention. Robert van der Elst's introduction to his French version (which has been out of print for many years) certainly is the most learned and most comprehensive interpretation made so far. In this introduction, Galen's work stands against the background of the philosophical and medical schools of Galen's era and Galen's own views of health and disease. Van der Elst traces the ethical implications to Platonic, Aristotelian, Pythagorean, and Stoic sources-the last

2. C. Daremberg, "Galien considéré comme philosophe," Gazette medicale de Paris, VI, No. 33 (1847), 643-45; C. Daremberg, La Médecine, histoire et doctrines (Paris: Dider \& $\mathrm{C}^{\prime}{ }^{\prime}$, and $\mathrm{J} . \mathrm{B}$. Baillière et Fils, 1865), pp. 84-98.

3. This treatise cannot be the same work which is herein translated and interpreted, since we know that Daremberg did not even allow a fragment of it to be incorporated into his incomplete French edition of Galen's writings. Robert van der Elst, from whom we borrow this passage, cites, however, on page 5 of his translation of Galen, two French authors, Chaignet and Chauvet-the first doing no more than mentioning the two treatises and summarizing the first one; the second, translating and interpreting just a few passages.

4. R. van der Elst, Traité des passions de l'áme et de ses erreurs par Galien (Paris: Librairie Ch. Delagrave, 1914), p. 43. 
being by far the dominant one according to Van der Elst's view of Galen's moral philosophy. Van der Elst's translation and interpretation have a most interesting and unique biographical source. It was the rise of psychotherapy in his own lifetime that attracted the French translator's attention to the treatise and aroused his scholarly interest in the philosophical and medical terms with which Galen treated the subject. It was only logical that Van der Elst's psychotherapeutical orientation led him to consider two major problems implied in this orientation-that is, first, the pathological nature of the passions and the criteria needed to identify this nature, and, second, the problem of their treatment. According to Van der Elst, it is only an individual's organic defect, some sort of a hereditary condition, an old infection, or a taint of insanity, that allows passion to be considered as an abnormal phenomenon, in brief, as we would say, a "symptom."5

We welcome Van der Elst's effort to link up the isolated datum of a passion with a biographical and pathological whole; indeed, this alone promises a consistent diagnosis to which we may ascribe regional.

5. The enlightened author of the once famous Motherby's Medical Dictionary (1795) must have had a similar idea in mind when he declared that symptoms indicate "morbid distress, or inability in the system," whereas signs "appear without any previous complaint affecting the habit." All symptoms may be signs, but all signs are not symptoms. Symptom, our author concluded, is "a praeternatural affection which follows disease, as a shadow the body." Signs are "declaratory of the state of the diseases as well as of something which has happened, or may occur in the machine; SYMPTOMS only of the presence and nature of the malady itself." In this perspective, passion appears to be a sign rather than a symptom. Though we mistake the instrument-i.e., the claw for the passion which it serves, cruelty the ancient saying "ex ungue leonem" is still revealing. 
physiological, pathological, etiological, and chronological constituents. But we understand passion to be part of man's basic equipments, not necessarily endangering, but often promoting health and growth; can passion as such ever be a symptom or should we not do justice to the Galenic definition of the symptom as a disordered function (functio laesa)? Galen reached this definition in one of his major works, De locis affectis. The definition leaves little room for the still widely accepted concept of the symptom in purely quantitative terms, i.e., the result of a greater than average intensity of a regional activity. Ultimately, one is referred to a disorder in the mutual relationship of all parts and segmented activities of the living organism; it is, we submit, from this disturbed relationship that symptoms may originate. ${ }^{6}$ It follows that only those passions can be called abnormal phenomena or symptoms which are rooted in a disruption of the reciprocal relationship of all of man's inclinations or propensities. Kant expressed himself in similar terms when, in his Anthropology, he defined passion as that inclination which reason when trying to make a choice is prevented from comparing with the totality of its inclinations. True, he did not hesitate to call passion a disease, which, as he said, detests all remedies and is therefore much worse than all those transient emotions which at least activate the intention to change for the better, unlike the passions which he believed to be true fascinations and incurable "cancerous sores." Kant

6. This view has been adopted by the author in his Principles of Neurology in the Light of History and Their Present Use (New York: Nervous \& Mental Disease Monographs, 1950), chap. xxix. 
did not seem to admit any fundamental difference between passion and disease. But it remains doubtful, to say the least, whether Kant, when dealing with the passions, wanted to leave to the term disease a clinical, rather than merely a metaphorical, meaning.

So strong has been at all times the suggestive power of the metaphor that those authors who believed passions to be diseases never failed to offer their designs for "treatment." The therapeutical method used by the Stoics, and adopted by Galen, was that of a direct and immediate attack of the passion; 7 this therapy was indeed, as Van der Elst said, no more than logic or ethics. In contrast, the twentieth-century psychotherapist refrains from a frontal attack on the symptom, but tries to recapture and to revitalize the biographical situation in which it originated, to expose its roots, to explore and disentangle the intricate tex-

7. I have been able to trace in the psychotherapy of insanity as practiced in the early nineteenth century (Reil, Heinroth, and others) the lack of any systematic attempts to uncover the roots of the disturbance and the dynamics of its symptoms. Symptoms were attacked immediately. What was intended was the immediate re-establishment of a definite conduct, sanctioned by the rules of society and tradition, moral standards, and religion. In other words, in the struggle between the mentally ill and reality, the latter was allowed to subdue the former without delay, without unfolding the abnormal psycho-dynamics at work, and without a preliminary slow, but progressive, adjustment that would allow the patient to strengthen his power and ability to meet the requirements of reality and, above all, to gain insight into the necessity of complying with them. The direct approach, not too well timed, necessarily led the psychotherapist to appeal to logic, reason, and convincing and persuading procedures, all of which were believed to act directly on the patient and to produce the intended conduct with no intermediate step. W. Riese, "The Impact of Nineteenth-Century Thought on Psychiatry," International Record of Medicine, 173: 7-19. 
ture of an individual's entire life and thought. But we have no reason to doubt that the ancients had their successes with their methods in their patients, who may have responded to procedures and techniques to which a twentieth-century patient would not respond-and vice versa. Not only does each period have its physicians, but its patients, and it is often the patient, who, himself a victim of the philosophical, educational, and social conditions of his time, forces the choice of the treatment upon the physician.

Van der Elst had no great esteem for Galen, the psychotherapist.8 The following case histories testify, however, to Galen's skill overshadowed, indeed, by his physiological psychotherapeutical system, the tyrannical influence of which remained unbroken until the nineteenth century and the rise of pathologic anatomy.

Galen was called to see a lady who was sleepless every night and in continuous agitation; he asked her several questions in order to trace the origin of the malady. Far from giving an answer, the lady turned her head away and covered herself with a veil as though she wanted to sleep. Galen retired; he thought that she was melancholic or affected by some secret sorrow; he postponed further examination until the next day. But on this second visit the slave on duty stated that his mistress did not appear. Galen again retired, came back a third time and again was dimissed by the slave asking him not to torment his mistress any longer, who, on the

8. It seems that the first professional psychotherapist was not a physician but an orator. We learn from Plutarch that Antiphon, a contemporary of Socrates, had a doorplate on his house at Corinth indicating that he was qualified to heal by words those who suffered from grief and melancholy; he comforted and consoled them by inquiring into the causes of their sufferings. 
second visit, had got up to wash herself and to take some food. The doctor cautiously did not insist; but he came back the following day and in a private conversation with the slave, he learned that the affection had its roots in a profound sorrow. At the very moment he looked at the lady, the name of the historian Pylades, pronounced by a person returning from a spectacle, produced a change in her color and facial expression. The pulse appeared accelerated; this did not happen when at that time or on the following occasion the name of another dancer was pronounced; the source of the lady's passion was no longer in doubt.

Pinel, who recorded this story in his Traité médico. philosophique sur l'alienation mentale, ${ }^{9}$ expressed his admiration for the rare sagacity displayed by Galen to discover a hidden psychic affection. It is regrettable, Pinel added, that Galen did not submit mental alienation to a special investigation.

... I diagnosed the case of a slave, who administered the household of another wealthy man, and who sickened in the same way. He was concerned about having to give an account of his expenses, in which he knew that there was a considerable sum wanting; the thought of this kept him awake, and he grew thin with anxiety. I first told his master that there was nothing physically wrong with the old man and advised an investigation to be made as to whether he feared his master was about to ask an account of the sums he had entrusted to him and for this reason was worried, knowing that a considerable amount would be found wanting. The master told me I had made a good suggestion, so in order to make the diagnosis certain, I advised him to

9. P. Pinel, Traité médico-philosophique sur l'alienation mentale (2d ed.; Paris: J. A. Brosson, 1809), p. xv. 
do as follows: he was to tell the slave to give him back all the money he had in hand, lest, in the event of his sudden death, it should be lost, owing to the administration passing into the hands of some other servant whom he did not know, for there would be no use asking for an account from such an one. And when the master said this to him, he felt sure he would not be questioned. So he ceased to worry, and by the third day had regained his natural physical condition. . . 10

Van der Elst contended that Galen, though, of course, not in possession of the observational and experimental implements of the modern concept of mental disease and their effects on therapy, could still have instituted a medical treatment, the ultimate target of which should have been neither the body nor the soul but their union. Van der Elst did not fail to recognize that a physician adopting this therapeutical design would invade metaphysics. In fact, the notion of the union of soul and body was considered by Descartes (in his letter of May 21,1643 to Princess Elizabeth) as one of the "primary notions, which are, as it were, the originals on the pattern of which we form all the rest of our knowledge ... and it is on this notion of their union that we have to depend for our notion of the force which the soul has of moving the body, and which the body has of acting on the soul, thereby causing its sentiments and passions." Van der Elst tried to uncover and to identify the metaphysical foundation on which the therapeutical methods of some of his eminent contemporaries (Charcot, De-

10. Greek Medicine: Being Extracts Illustrative of Medical Writers from Hippocrates to Galen, translated and annotated by Arthur J. Brook (London and Toronto: J. M. Dent \& Sons, L.td.; and New York: E. P. Dutton \& Co., 1929), p. 214. 
jerine) rested. I doubt that they were prepared to accept this disclosure with enthusiasm. But I am almost sure that with rare exceptions the mid-twentiethcentury physician would defend the invasion of his experiential grounds by metaphysics with obstinacy. The historical account of the origins, substance, and after-effects of Galen's treatise on the passions would be incomplete were it not to include the following statement made by the late eminent historian of science, George Sarton:

... Strangely enough, he devoted less attention to ethics than to logic, but one of his ethical treatises is perhaps the most readable of the whole Galenic corpus. It is a treatise on the passions of the soul and its errors, which is the more interesting because it includes autobiographical reminiscences. The burden of it is that the "errors" are the results of false judgments or opinions, and the "passions," of unbridled energy, disobedience to reason. The various passions (anger, lust, fear, melancholy, greed, gluttony, etc.) are examined one by one, and he offers psychotherapeutic guidance. Galen did not accept the old Stoic doctrine assimilating diseases of the soul to diseases of the body. Following Poseidon. ios (130 -50 B.C.), he considered that the psychical troubles were comparable more to the body's predisposition to disease than to the disease itself. He recommended the practice of self-examination daily or many times a day, illustrating it with his own experience. He went so far as to repeat aloud twice a day the maxims which Pythagoras had devised for self-improvement.11

Twice in recent years I have submitted an analysis

11. G. Sarton, Galen of Pergamon ("Logan Clendening Lectures on the History and Philosophy of Medicine," Ser, 8 [Lawrence, Kan.: University of Kansas Press, 1954]). 
of Galen's moral thought. Here is the English version of the crucial passage in my Pensée morale en médecine; 12

What is generally lacking in the ethics of the ancients is the element of confict and struggle. Far from passing through the crisis of conscience, so characteristic of modern man facing decision and action-man, according to Aristotle, is just if he feels joy in accomplishing just actions, he is generous if he delights in generous actions. And the philosopher concludes, "Actions which conform to virtue, are agreeable in themselves." 13 Galen, in his treatise "That the morals of the soul are the consequence of the temperament of the body ...." sustains the thesis that the good and the bad are such as they are because of the temperament of the body. To his adversaries, afraid that the right to praise or to blame, to hate or to love might be denied to them, Galen replies that we are endowed with the innate faculty to prefer, to seek, to love the good, to turn away from evil, to hate and to avoid it "without considering whether or not it was engendered. ..."14 If it be true that "the prince of the physicians" does not explicitly declare, like Aristotle, 15 that one feels joy in accomplishing just actions, the love of the good, none the less, implies the pleasure which one always feels in obeying the innate faculties. However, the attitude of modern man toward the good is utterly different. If he happens to love it, and if his love manifests itself by acts and not only by gratuitous admiration, then it is only after

12. Translated and quoted by permission of Presses Universitaires de France, Paris.

13. Ethique de Nicomaque, texte, traduction, Préface, et notes par Jean Voilquin (Paris: Editions Garnier Frères, n.d.), p. 29.

14. C. Daremberg, Oeuvres anatomiques, physiologiques et médicales de Galien (Paris: J. B. Baillière, 1854), I, 85.

15. Ethique de Nicomaque, PP 29, 145 
having passed through conflict16 and after having resisted the initial love of evil and temptation. The dramatic conflict between desire and duty cannot be found in Galen. If drama there be, it will not happen within the mind of the physician of antiquity.

But the terms which to the physician translate in the most evident manner the non-combative nature of Galen's concept of virtue are those of diathesis and of disposition. This same nature is already implied in the Platonic and Aristotelian definition of ethics as wisdom and measure, but also in this Platonic idea, used later by Aristotle, the idea according to which justice and morale at large are the proper functions of the soul, as sight is that of the eye; man, to be virtuous and happy, only has to exercise his proper functions. One sees springing from this idea the danger of a physiological interpretation of ethics; one will find it again in Galen. Aristotle defines virtues in a most explicit manner, as acquired dispositions. "Moral virtue is the daughter of good habits." Thus it is neither the effect of nature nor contrary to nature that virtues develop in us; we are naturally predisposed to acquire them with the view of perfecting them by habit.17". . . It is through practicing justice that we become just, temperate, and courageous."

These Aristotelian and Galenic interpretations seem to ignore the always creative element of any moral de-

16. It is true that Aristotle, in his Nichomachean Ethics, admits deliberation and choice (iii. 5), and that, according to him, goodness and vice are based precisely on choice. However, he does not discuss the state of mind which is characterized by choice in suspense and which, in my opinion, distinguishes modern from ancient man. But Aristotle, as well as the Greeks in general, is mainly a metaphysician, and the psychological effects, from which metaphysical facts ensue, play no part in his preoccupa. tions. That is to say that conflict, a psychological phenomenon of first importance, although derived from a metaphysical fact, introduces an element new and foreign to the thought of the ancients.

17. Ibid., ii. 1. 
cision, to which they confer a somewhat lazy element. As I have previously said, in morals each law has, so to speak, its given name.18 But what seems particularly characteristic of Galenic ethics, and certain recent versions of ethics, is the identification of nature with morals. It is difficult to understand how, then, a confict can originate within the same power, i.e., nature; and above all, how, from certain evolutionary stages on, purely instinctive and unconscious behaviors are able to engender consciousness, which, however, remains the reference mark in all comparative studies of ethical thought.

On September 11, 1960, I delivered to Société Moreau de Tours (Paris) my lecture on Galen's moral thought ("La pensée morale de Galien"), which is to be published by Revue philosophique. In this lecture I distinguished three major constituents of Galen's moral thought. Of the three, the Aristotelian "mean" is stressed in the treatise on the soul's passions repeatedly and forcefully. The terms used are those of moderation and temperance. But also the second constituent, i.e., habit, is cited as a royal road leading to moral growth, i.e., liberation from the passions; the terms used in reference to habit are training and practice. There is an undeniable educational undercurrent in the whole treatise. So strong was Galen's trust in the effect of habit and training that he believed that he could render the concupiscible power small and weak simply by not furnishing it with the enjoyment of the things it desires. The twentieth-century reader may be expected to identify the mechanism called for by

18. W. Riese and A. Réquet, L'idee de lhomme dans la neurologie contemporaine (Paris: Félix Alcan, 1938). 
Galen as that of the extinction of conditioned reflexes, though, of course, Galen, far from even having the slightest pre-notion of reflex activity and its experimental analysis (a product of the nineteenth and twentieth centuries), remained strictly observational and biographic.

The educational character of the treatise is strongly affirmed by Galen's repeated insistance upon frequent self-examinations and the guidance by an overseer, -supervisor, or tutor. In the choice of the latter, priority should be given to fearless, independent, and, preferably, old men, who had freed themselves from their own passions. In contrast, it has become the tendency of modern psychotherapy to shift the qualification of the psychotherapist from his personality to his allegiance to a definite school of thought and to his tested mastery of the technique applied by the latter. The Galenic method may be said to imply the danger of improvisation, uncontrolled inspiration, unsystematic and unorganized psychotherapy; the modern method implies the danger of indoctrination.

The third constituent of Galen's moral thoughti.e., the temperament of the body, or, in more general terms, nature-is cited only occasionally in Galen's treatise as a morale-forming factor and, significantly enough, only in connection with the behavior of children and in its educational implications. Of all philosophical doctrines which reached Galen through his teachers in his early years, it was the Stoic teaching which left the most visible mark on the treatise herein translated by Paul Harkins and interpreted by me. This is borne out unquestionably by the very principle of conduct and therapy adopted and reaffirmed by 
Galen throughout the treatise, namely to eradicate the passions. It is also clearly demonstrated by the ultimate goal for which man should strive, i.e., apathy. Last but not least, the Galenic interpretation of the passions as diseases of the soul can be traced to the Stoic school and its founder Zeno, whose name is cited in the treatise.

There is, however, one most interesting passage in which Galen approaches another method of treating the passions, no longer considered as intrinsically and irrevocably evil and as calling for no other treatment than to be eradicated. Passions, he confessed in this passage, should not necessarily be condemned to total extirpation; they should be used. You might use the irascible power itself, we read in this passage, to help you fight against the other power, which the philosophers of old called the concupiscible. Sketchy as it is, this passage implies the view of an instrumental role of the passions.

It was Descartes who, ffteen centuries later, adopted the same view. We read in Article 52 of The Passions of the Soul: "The objects which move the senses do not excite diverse passions in us corresponding to all diversities which are in them, but only in accordance with the diverse ways in which they can injure or profit us, i.e., only in so far as they are, to use a general term, of concern to us. The manner of operation of the passions, one and all, consists in this, that they dispose the soul to will the things which nature tells us are of concern to us, and to persist in so willing." Since he believed the passions to be "instituted" by nature, he unmistakably adopted a teleological, if not an Aristotelian and Galenic interpretation of vital 
phenomena, thus transgressing that purely mechanistic view of animate nature for which he has been made responsible for centuries. In contrast, passions emerged from the Cartesian texts as true organs. Nor was Descartes satisfied with the instrumental role of the passions in general and abstract terms; he described in detail and in concrete terms the utility of a number of them. He thus offered a teleological interpretation of pain as a warning against imminent physical harm. It excites in the soul the passion of sadness ("tristesse"), succeeded in its turn by that of hatred ("haine") of the cause of pain and finally the desire to get rid of it. Similarly, the passion of joy succeeds the feeling of titillation ("chatouillement") by which the soul is informed about the things beneficial to the body; then the passion of love (of the presumable cause) originates, succeeded in its turn by the desire to obtain the cause of the feeling of titillation.

Should Descartes have been familiar with Galen's treatise on the soul's passions, I could have traced a third Galenic source of the great French philosopher; 18 but perhaps we must turn to Peripatetic sources of the

19. W. Riese, "Descartes's Ideas of Brain Function. Lecture Delivered on July 15, 1957, in London to the Anglo-American Symposium on the History and Philosophy of Knowledge of the Brain and Its Functions. Organized in Connection with the First International Congress of Neurological Sciences (Brussels), and Sponsored by the Wellcome Historical Medical Library with the Co-operation of the National Hospital Queen Square, and the Maudsley Hospital, London," in The History and Philosophy of Knowledge of the Brain and Its Functions, ed. F. N. L. Poynter (Oxford: Blackwell Scientific Publications, 1958), pp. 115.34; W. Riese and L. Bourgey. "Les Gracieusetés à l'égard des malades (Commentaire de Galien sur épidémies, VI, section 4, division 7)," Revue philosophique de la France et de letranger, 150: $145-62$. 
doctrine of the uses of the passions on which Galen himself might have drawn. Cicero referred to them in his Tusculan Disputations, condemning the doctrine of the instrumental power of the passions and clinging to the integral Stoic prescription to eradicate them altogether.

But I feel strengthened in my thesis of a Galenic source of the Cartesian doctrine of the uses of the passions by giving weight to another parallel between Galenic and Cartesian texts. It is the element of delay ${ }^{20}$ which emerges from both texts as a common

20. Delay as a therapeutical device appears for the first time (at least to my knowledge) in Seneca's moral essay On Anger; the crucial passage reads as follows: "...The cause of anger is an impression of injury, and to this we should not easily give credence. We ought not to be led to it quickly even by open and evident acts; for some things are false that have the appearance of truth. We should always allow some time; a day discloses the truth." The method to delay action in a state of anger reappears in Plutarch's (46-120 A,D.) biography. Again, the method is illustrated by the angry master setting out to punish a slave who has committed a fault. I discovered the crucial passage in the biography of Plutarch by Dacier (see below). The thesis of an instrumental role of the passions is a recurrent theme in Plutarch's moral writings, from which he emerges as one of the first explorers of human passions, their genesis, their nature, and their domination. Finally, I quote Plato's (428.347 B.c.) advice to "enlist" anger on the side of reason; the passage is to be found in the "Timaeus" and reads in Cornford's interpretation and translation as follows: "Plato's 'spiritual element" is a group of emotions and sentiments whose most characteristic expression is seen in anger, indignation, ambition for success and victory, the love of power. In the conflict of motives, as the Republic showed, these feelings can be enlisted on the side of reason against the impulses of lawless appetite, that mob of lower desires which must be kept in order by restraining force if reason is to rule. ..." Seneca, Moral Essays, trans. John W. Basore (London: W. Heinemann, Ltd.; New York: G. P. Putnam's Sons, 1928), I, 2I5; Dacjer, Les vies des hommes illustres pour servir de supplement aux vies de Plutarque (Nouvelle édition; Paris, 1803), tome 12', An Xi, 458: "Timaeus," in Plato's Cosmology, translated, with a running commentary, by Francis MacDonald Cornford (London: Routledge \& Kegan Paul, Ltd., 1948). p. 284. 
psychotherapeutical design in states of violent passion. "It is much better to inflict the punishment when you are no longer boiling with passion and after you are free from your unreasoning anger ..." (Galen).

Descartes, in The Passions of the Soul (Article 46), says, "It is easy to overcome the lesser passions, but not those that are more violent and powerful; we have to await the abating of the commotion in the blood and spirits. ... . "

The main subject of the second treatise is the search for a method of scientific demonstration. It is well known that the theory of scientific demonstration was the subject of Galen's principal philosophic work, which, unfortunately, has not come down to us. But its substance was tentatively and ingeniously reconstructed by Iwan von Müller ${ }^{21}$ out of Galen's own references and citations in his other writings and from quotations in the Greek, Syriac, Arab, and Jewish authors of the Middle Ages. At first approach, the second treatise seems to be unrelated to the first one. But the repeated reference made to the passions (vain boasting, self-love, ambition, concern for reputation, conceit of wisdom, and love of money) as the obstructive forces standing in the way of controlled unprejudiced reasoning definitely links the second treatise with the first one. Galen here proved to be the first unmasking psychologist.

A still more solid chain of thought leading from the treatise on passions to that on errors is evidenced by the following statement contained in the latter: "Every-

21. I. Müller, Uber Galens Werk vom wissenschaftlichen Beweis (München, 1895). 
one agrees that a false opinion regarding the end of life leads to a miserable life."

There is an undeniable similarity between the problems discussed and answered by Galen in this second treatise and the reconstructed contents of the lost work on the theory of scientific demonstration. In both treatises, Galen reached the fundamental distinction between knowledge gained by the immediacy of sensual intuition and that gained by conceptual or logical processes not assisted by any sense perception. In the first kind of knowledge, "the fact itself will bear witness to you"; the question is decided "by the very subject matter"; the solution is "clearly seen." He took his examples from geometry. Unquestionably, he remembered and reaffirmed his father's training and scientific preferences. But he also anticipated, in the crude terms of his era, problems which eighteen hundred years later became known as the fundamentals of transcendental esthetics and transcendental logic.

The treatise may be said to reach its climax in those passages in which Galen outlines, though in a very sketchy manner, his theory of experience. The Aristotelian "analysis" emerges as the crucial concept. This is not understood simply to be a decomposition of a complex of ideas or data into their constitutive elements. It originates from the search for an ultimate or a "primary" criterion of truth. The man who looks to this criterion must bring all things back to it, one after another. The criterion must be irreducible, and Galen warned his readers not to continue endlessly the search for the primary criterion and, subsequently, analytic process.

He could not assist his readers in their need for a 
definition or universal qualification of the primary criterion of truth. Human intelligence had to wait eighteen hundred more years to learn from Kant's discovery of the antinomies that the regressus ad infinitum against which Galen warned his readers is unavoidable as long as human understanding remains within the field of the empirically explorable and that experience offers no absolute limit to the endless number of steps which the searching mind is free and compelled to make in order to reach a first principle of genesis, causality, extent, and division of our phenomenal world. Only by stepping out of his experience can man hope to reach the first principle, but then he is a metaphysician. It testifies to Galen's profound philosophical sense and culture to have raised these problems, though he could neither be expected to solve nor to express them in the terms of the eighteenth century.

Still another passage provokes the same admiration for Galen's exploring mind and his ability to find the first formulae for fundamental and lasting problems of natural philosophy. Galen-again, in a very sketchy manner-outlined a natural history of man's reasoning power. First, he says,

... the elementary theorems were investigated and discovered; then came men of a later day who added to these theorems that most marvellous reasoning which, as I said, is called analytic; thereafter, both these men and others who were willing to learn exercised themselves in this analytic reasoning to the greatest extent. . . These men brought to themselves the truest honor; they were eager to exercise the noblest power in their soul and to bring that power to its perfection. Obviously, I mean the power of reason. When this be- 
comes vigorous through exercise, these men enjoy themselves more than those who are slaves to bodily pleasures. Surely, it is because of no other power that we differ from goats or dogs or swine or sheep or asses; no other contemplation brings greater delight to the soul of a man of good natural disposition than does the process of analytic reasoning, at least whenever a man is making progress in it.

Again, we identify in these passages two of the major constituents which we distinguished in Galen's treatise on the passions and in his moral thought, i.e. "good natural disposition" and "practice." But the most interesting and significant component in this passage is the Galenic criterion of the natural history of reason. In this history man evidently did no more than to bring the power of reason to its perfection. It is not said that the power of reason sprang from a purely natural or-to speak in terms of the nineteeth centurypurely instinctive soil. In other words, the end of this genesis is quasi-anticipated or enunciated by its first link (i.e., the elementary theorems) which thus emerges as the archetype of a metamorphosis (Goethe) . We are able to identify in these views the basic structure of Galen's physiology revealed, most clearly, in his treatise $O n$ the Natural Faculties.

That Galen is the author of the treatises translated here has never been questioned, but we submit that their genuineness is substantiated by the internal evidence that this interpretation has attempted to convey to the reader. 



\section{INDEX}

Academics, the, 75, 99, 100

Achilles, 87

$\operatorname{Act}(8), 35,99,49,121$; in anger.

28 ; of a geometrician, 74 ; of intellectual power, 73; of stinginess, 67 ; of thrift, 68

Aesop, 30, 31, 78

Agamemnon, 37

Air clocks, 82,

Ajax, 87

Aldine manuscript, 23, 24

D'Alembert, J., 111

Alexandria, 1, 2

Analogy, method of, 6

Analysis, Aristotelian, 129

Analytic reasoning, Galen on, 9596

Anatomy, 10, 14

Anima mundi, 15

Antonius the Epicurean, 27, 29 Aquileia, 2
Aristides the Just, 55

Aristotle, 11, 20, 28, 112, 121, 122

Asclepiades, 6

Aspasius the Peripatetic, 58

Bell, C., 17

Boer, W. de, 23, 24

Bourgey, L., 21

Causal thought, 8

Charot, J., 119

Chrysippus, 28

Cicero, 127

Cinyras, 65

Commodus, 3,18

Conceptual unity, 8-9

Concupiscible power, the, 46-48, 123 
Consistency of disease, 5,7

Convulsions, 17

Corinth, 40

Covetousness, 63, 65, 66, 68

Cynic(s), the, 83

Daremberg, C., 113

Dejerine, 119.20

Descartes, 119, 125, 126, 128

Diarrhoea, 61

Diathesis, 13, 122

Diderot, 111

Diogenes Laertius, 36

Diomede, 37

Disordered function (functio lae. 5a), 13, 115

Dissection, 14, 16

Dogmatist(s), the, $4,5,6,9,10,12$

Dycrasia, 14

Eleusis, 40

Elizabeth I, 119

Elst, R. van der, 113, 114, 116, 117 . 119

Empiricists' philosophy of medicine, $4-6,7,8,9$

Envy, 32, 49, 53

Epicurean(s), 58, 99, 106

Error, 78-107; definition of, 28, $73-79,120$; recognition of, 29-31, 52, 53-54, 68-69

Ethics, 120, 122, 123

Etiology, 13

Euclid, 74

Eucrasia, 13

Eupolis, 55

\section{Facies hippocratica, 11}

Function: of disease, 10; of irascible power, 47; of pneuma physicon, 15-16; of preuma roti. kon, 16; of the soul, 122
Gaius, 57

Galenism, 10-14, 16, 20

Geometry, 58, 74, 78, 81, 82, 95, $98,107,129$

Glory, 59, 65, 67, 68

Gluttony, 46, 48, 50, 67

God, 19, 20, 34

Goethe, 131

Gortyna, 39

Greed, 53, 60, 68, 65, 66, 103

Grief, 82, 43-44, 53, 54, 55, 59, 60, $63,64,65,67$

Habit, 36, 38, 51, 56, 102, 122, 123

Hadrian, 18, 39

Happiness, 64, 75-76, 81, 83, 84, 88, 122

Health, 37, 61-62, 62, 113, 115; of the soul, 38; as state of equilibrium (eucrasia), 18

Healthful foods, 50,51

Heart, 15, 16

Hemiplegia, 17

Hercules, 37

Hesiod, 97

Hippocrates, 6, 12, 20, 21, 76

Hippocratism, 10.13

Honigmann, G., 15

Honor(s), 32, 43, 56, 59, 64, 65, 67. 77,95

Hydrostatic clocks, 81

Insatiate desire, $60,61,63,65,67$ Insolence, $\mathbf{3 5}$

Irascible element, the, 41

Irascible power, the, $46,47-58,125$

Irrational power, the, 28, 46, 47, 48,73

Jackson, \., 17

Joy, 126 
Kant, Immanuel, 115, 116, 130

Kuehn, C., 24

Laurentian manuscript, 23,24

Liver, the, 15

Logical structure of reality. 10 Logos, 4, 5, 9

Love, 69,126 ; of evil, 122; of glory, $59,65,67,68$; of the good, 12]; of money, 83, 128; of pleasure, 88 ; of reputation, 66 ; of strife, 65

Lust, 44, 49, 67; for power, 53, 65,66

Lynceus, 98

Macrocosm, 12

Magendre, F., 17

Maïmonides, Moses, 20

Marcus Aurelius, 2, 8

Marquardt, 23, 24

Master builder, the, 104, 105

Medical etiquette, 21

Medical experience, Galen's theory of, 4

Medical profession, 76

Megara, 40

Microcosm, 12

Midas, 65

Moderation, 32, 50, 61, 123

Mueller, I., 24

Müller, Iwan von, 128

Nature, 124, 125, 126

Neuburger, M., 14

Nikon, 1

Noblest power, 95

Overseer, 52, 66, 67, 68, 124
Paracelsus, 14

Paralysis, 17

Passion, 27-69, 83, 111, 112, 114 , $116,119,120,123,125,126,127$, 128; definition of, 32,115

Patient, the, 13, 117

Patroclus, 37

Perceptible constituents, 8

Pergamum, 1, 2

Peripatetics, the, 99, 106, 126

Philopater, 57

Physis, 10

Pine1, P., 12, 18, 118

Plato, 15, 19, 28, 31, 42, 112

Pleasure, 46, 48, 62, 75, 88, 96, 121

Pneuma, 15

Pneuma physicon, 15, 16

Preuma zotikon, 16

Pneumatists, 15

Poseidonios, 120

Power of reason, 96, 98, 131

Prince of Physicians (Galen), \$, 20, 121

Procedure, medical, 7

Prognostical symptoms, 6

Psychology, 111

Psychopathology, 111

Psychotherapy, 20, 21, 112, 114. $116,119,120,124$

Pylades, 118

Pyrrho, 75

Pythagoras, 49,120

Pythian dictum, 29

Rashness, 103

Reason, 28, 43, 44, 46, 47, 73, 93, $96,107,112,115,120,131$

Romans, the, 93

Rush, B., 18

Sarton, George, 1, 15, 120

Self-control, 49,51 
Self-discipline, 50-51

Self-love, 31, 77, 82, 83, 128

Self-sufficiency, 64,65

Sensation, 16, 17

Senses, the, 9, 101, 102, 103, 125

Singex, C., 1, 20

Skeptics, the, 99,100

Smyrna, 2

Socrates, 57

Sophisms, 84, 85

Soul, the, 14, 15, 119, 120, 121, $122,126,130,131$; errors of, 73-107; passions of, 27-69; Platonic theory of, 15

Spinal cord, 12, 16, 17

Spirit, the, 15, 16

Sprengel, K., 112, 119

Stoics, the, 2, 15, 21, 99, 106, 112, $113,116,120,125$

Sundial, 74, 90-95, 96

Sydenham, Thomas, 17

Symptom(s), 5, 6, 7, 9, 13, 61, $114,115,116$

Symptom-formation, 7

Synthesis, 90.91

Synthetical thought, 10, 11
Temperance, 50-51, 58, 59, 123

Thersites, 37

Thrasybolus, 13

Thriasian Plain, 40

Tutor, 50, 66, 124

Unconscious behaviors, 123

Venice, 2

Vesalius, A., 14

Virchow, R., 18

Virtue, $50,5 \mathrm{k}-52,59,64,68,74$, $75,83,97,121,122$

Vitalism, il

Void of the universe, 100, I04, 106

Waterclock, $81,93-96$

Xanthippe, 57

Zeno, 35, 36, 125 